\title{
A nuclear cap-binding complex facilitates association of U1 snRNP with the cap-proximal 5' splice site
}

\author{
Joe D. Lewis, Elisa Izaurralde, Artur Jarmolowski, ${ }^{1}$ Caroline McGuigan, and Iain W. Mattaj ${ }^{2}$ \\ Gene Expression Programme, European Molecular Biology Laboratory (EMBLi, 69117 Heidelberg, Germany
}

The mechanism by which intron-containing RNAs are recognized by the splicing machinery is only partly understood. A nuclear cap-binding complex $(C B C)$, which specifically recognizes the monomethyl guanosine cap structure carried by RNA polymerase II transcripts, has previously been shown to play a role in pre-mRNA splicing. Using a combination of splicing complex and psoralen cross-linking analysis we demonstrate that $\mathrm{CBC}$ is required for efficient recognition of the $5^{\prime}$ splice site by U1 snRNP during formation of $E$ (early) complex on a pre-mRNA containing a single intron. However, in a pre-mRNA containing two introns, CBC is not required for splicing of the cap distal intron. In this case, the presence of an intact polypyrimidine tract in the cap-proximal intron renders splicing of the cap-distal intron independent of CBC. These results support models in which the splice sites in a pre-mRNA are originally recognized by interactions spanning exons. The defects in splicing and U1 snRNP binding caused by CBC depletion can be specifically reversed by recombinant CBC. In smmary, efficient recognition of the cap-proximal 5 ' splice site by U1 snRNP is facilitated by CBC in what may be one of the earliest steps in pre-mRNA recognition. Data in Colot et al. (this issue) indicate that this function of $\mathrm{CBC}$ is conserved in humans and yeast.

[Key Words: Splicing; nuclcar cap-binding complex; pre-mRNA; UlsnRNP; 5' splice site]

Received January 23, 1996; revised version accepted April 2, 1996.

Removal of introns from pre-messenger RNAs (premRNAs) occurs in a dedicated nucleoprotein complex termed the spliceosome. The spliceosome consists of $\mathrm{U} 1, \mathrm{U} 2$, and U4/U6.U5 snRNP particles together with a large number of nonsnRNP splicing factors, most of which are poorly characterized (for review, see Lamm and Lamond 1993; Moore et al. 1993; Madhani and Guthrie 1994). The cis-acting elements which define introns, the 5' splice site, branchpoint sequence, polypyrimidine tract, and $3^{\prime}$ splice site, have quite degenerate sequences in higher eukaryotes. This poses the problem of how pre-mRNAs are efficiently recognized by the splicing machinery in spite of the limited amount of sequence information.

In vitro, several stable intermediate complexes in the spliceosome assembly pathway have been observed. In mammalian nuclear extracts, the first prespliceosomal complex to be observed is the early (E) complex, which forms in the absence of ATP (Michaud and Reed 1991). The E complex contains U1 small nuclear ribonucleoprotein (snRNP) and the splicing factor U2AF (U2 snRNP auxiliary factor; Zamore and Green 1989/ bound at the $5^{\prime}$ splice site and polypyrimidine tract, respectively.

\footnotetext{
${ }^{1}$ Present address: Institute of Molecular Biology and Biotechnology, Department of Biopolymer Chemistry, Miedzychodzka 5, 60371 Poznan, Poland.

${ }^{2}$ Corresponding author.
}

Additionally, other less well characterized proteins are found associated with E complex (Bennet et al. 1992a). This complex is probably the mammalian equivalent of the yeast commitment complex (Séraphin and Rosbash 1989; Abovich et al. 1994) whose formation represents the first definitive commitment of a pre-mRNA to the splicing pathyway in Saccharomyces cerevisiae (for revicw, see Rosbash and Séraphin 1991; Hodges and Beggs 1994). Next, U2 snRNP is added to the E complex, in a step that requires ATP, to form the A complex. The U4/ U6.U5 tri-snRNP then joins to form the mature spliceosome within which the two transesterification reactions take place to produce the mature mRNA and intron lariat (for review, see Moore et al. 1993).

In recent years much has been learned of the contributions the U snRNPs in defining the $5^{\prime}$ and $3^{\prime}$ splice sites (for review, see Madhani and Guthrie 1994; Newman 1994). However, the role of non-snRNP splicing factors in pre-mRNA recognition is less well understood (Lamm and Lamond 1993). It has been demonstrated previously that the presence of 5 ' cap structure plays an important role in efficient splicing of pre-mRNAs in mammalian cell extracts |Konarska et al. 1984; Krainer et al. 1984; Edery and Sonenberg 1985; Ohno et al. 1987; Patzelt et al. 1987) and also in vivo (Inoue et al. 1989). A nuclear cap-binding complex $(\mathrm{CBC})$ had been characterized and cloned previously. CBC specifically recognizes the cap structure \{Izaurralde et al. 1994, 1995\} and con- 
Lewis et al.

sists of two subunits, cap-binding proteins 80 and 20 (CBP80 and CBP20), both of which are required for specific binding to capped RNAs in vitro (Izaurralde et al. 1995; Kataoka et al. 1995). Depletion of CBC from splicing extracts or injection of anti-CBP20 antibodies into Xenopus oocytes was found to markedly reduce splicing of a pre-mRNA containing a single intron derived from the adenovirus major late transcription unit, leading to an accumulation of unspliced pre-mRNA. Analysis of the kinetics of spliceosome assembly showed a major defect in A complex formation in depleted extracts compared to control extracts, suggestive of a role for CBC at, or prior to, A complex assembly (Izaurralde et al. 1994, 1995).

In this report we have characterized the defect in splicing and splicing complex assembly caused by CBC depletion from HeLa cell nuclear extracts. In addition, we examine the effects of CBC depletion on the splicing of cap distal introns. We find that E complex assembly, and more specifically, the association of Ul snRNP with the cap-proximal $5^{\prime}$ splice site, occurs inefficiently in extracts depleted of CBC. The defects in CBC-depleted extracts can be fully complemented by recombinant $\mathrm{CBC}$ $(\mathrm{rCBC})$. This suggests an important role for $\mathrm{CBC}$ in the earliest steps of pre-mRNA recognition. Other results (Colot et al., this issue; J. Lewis et al., unpubl.) indicate that $\mathrm{CBC}$ carries out this function not only in mammalian cells but also in yeast.

\section{Results}

We have previously characterized and cloned cDNAs encoding both subunits, CBP80 and CBP20, of nuclear CBC from HeLa cells. Using antibodies raised against the individual subunits it has been possible to demonstrate a role for this complex in both pre-mRNA splicing and nuclear export of the RNA polymerase II transcribed spliceosomal U snRNAs (Izaurralde et al. 1994, 1995). Recombinant CBC purified from Escherichia coli lysates is able to bind to the cap structure with a specificity which is indistinguishable from $\mathrm{CBC}$ present in HeLa cell extracts (Fig. 1A). The HeLa CBC activity and $\mathrm{rCBC}$ produce a similar mobility shift when bound to the capped RNA probe. Both activities are efficiently competed with $\mathrm{m}^{7} \mathrm{GpppG}$ and et ${ }^{7} \mathrm{GpppG}$ (Fig. 1A, lanes $4,7,12,15$ ) but not, for example, with $\mathrm{m}^{2,2,7} \mathrm{GpppG}$ (lanes $6,14) \cdot \mathrm{m}^{2,7} \mathrm{GpppG}$ has an intermediate competitive efficiency (lanes 5,13). This demonstrates that a complex of CBP80 and CBP20 is sufficient to bind specifically to the

\section{A}
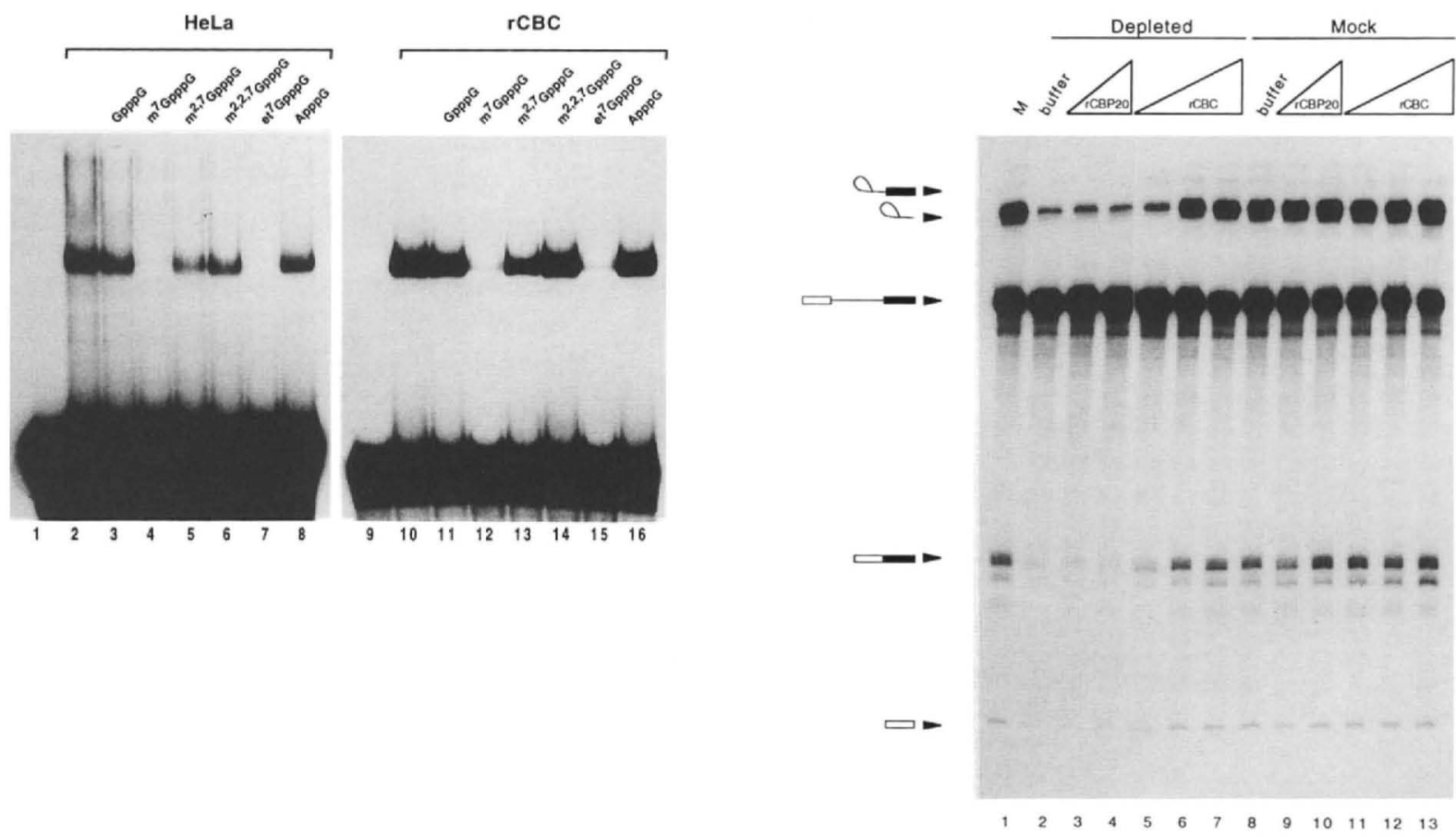

Figure 1. Cap specificity of $\mathrm{rCBC}$ and complementation a $\mathrm{CBC}$-depleted extract. $(A)$ Complexes formed between a $\mathrm{m}^{7} \mathrm{GpppG}$-capped RNA probe and either HeLa nuclear extract $(0.8 \mu \mathrm{g})$ or recombinant CBC $(50 \mathrm{ng})$ were fractionated by native gel electrophoresis. Competitor dinucleotide analogs of the cap structure, as indicated at the top of each lane, were added to a final concentration of either $100 \mu \mathrm{M}$ (to the HeLa extract); or $200 \mu \mathrm{M}$ (to the CBC). (Lanes 1,9) Probe alone; (lanes 2,10) control. (B) The adenovirus pBSAdl pre-mRNA was spliced in mock-depleted (lanes 1,8-13) or CBC-depleted (lanes 2-7) extract. Extracts were supplemented with buffer (lanes 2,8), increasing amounts of recombinant CBP20 (rCBP20, lanes 3,4,9,10), or increasing amounts of rCBC (lanes 5-7, 11-13). Splicing reactions were allowed to proceed for $2 \mathrm{hr}$. Products of the splicing reaction were then resolved on a $10 \%$ denaturing urea-polyacrylamide gel. 
cap, although neither subunit binds detectably on its own (E. Izaurralde, J. Lewis, and I. Mattaj, unpubl.).

Depletion of CBC from nuclear extracts inhibits splicing of uniformly labeled $\mathrm{m}^{7} \mathrm{GpppG}$ capped $\mathrm{Adl}$, a premRNA derived from Adenovirus 1, by $\sim 90 \%$ (Izaurralde et al. 1994; and Fig. 1B, lanes 1,21. Previously we have shown that addition of CBC purified from HeLA nuclear extracts could restore splicing to a depleted extract, whereas recombinant CBP80 alone had no stimulatory activity. We were interested to determine whether $\mathrm{rCBC}$ or rCBP20 would be able to restore splicing to CBC depleted extract. $\mathrm{rCBC}$ and $\mathrm{rCBP} 20$ were prepared from $E$. coli lysates as described previously (Izaurralde et al. 1995). Addition of rCBP20 alone to extracts that had been depleted of CBC by passage over an anti-CBP80 antibody affinity column had no stimulatory effect on splicing either in depleted extract (Fig. 1B, lanes 3,4) or in mock-depleted extract (lanes 9,10 ). In contrast, addition of increasing amounts of rCBC to the depleted extract (lanes 5-7) restored splicing to levels similar to those observed in control reactions (lanes 1,8 ). Importantly, the same amounts of rCBC added to mock-depleted extract did not cause any stimulation of splicing (lanes 1113), demonstrating that $\mathrm{rCBC}$ was replacing the depleted activity rather than causing a general increase in splicing efficiency. These results demonstrate that $\mathrm{rCBC}$ can functionally substitiute for the endogenous complex in pre-mRNA splicing.

\section{$C B C$ is required for early steps in prespliceosome complex assembly}

Spliceosome assembly proceeds in a defined order. The first specific complex to be observed, formed in the absence of ATP, is the E complex. This complex contains U1 snRNP, U2AF, and several other proteins (see introductory section|. In the next step U2 snRNP is added, in a process that requires $A T P$, to form A complex. We previously demonstrated that $\mathrm{CBC}$ depletion caused a large reduction in the efficiency of assembly of the ATPdependent A complex (Izaurralde et al. 1994). Because complex formation was assayed by native gel electrophoresis, in which E complexes are not resolved (Michaud and Reed 1991), we were unable to determinc whether $\mathrm{CBC}$ was required at the stage of, or before, A complex formation.

To further analyze the role of CBC, E complex assembly was analyzed by gel filtration (Michaud and Reed 1991). Reactions were set up using extracts depleted of ATP (see Materials and methods). Parallel samples from either CBC-depleted or mock-depleted extracts were examined. Uniformly labeled Adl pre-mRNA was added to each reaction and incubated for $15 \mathrm{~min}$ to allow $\mathrm{E}$ complex formation, then fractionated by gel filtration. A complex with the mobility characteristic of $E$ complex forms both in mock-depleted and CBC-depleted extract (Fig. 2A). These complexes were not observed using an antisense Adl transcript as a control (data not shown). The level of complex assembly observed with depleted extracts was calculated from the distribution of labeled
RNA between the $\mathrm{E}$ and $\mathrm{H}$ complexes, and was consistently on the order of $50 \%$ lower that that observed in the control reaction / a decrease in the amount of $E$ complex leads to a corresponding increase in the height of the $\mathrm{H}$ pcak; the efficiency of assembly is calculated from the ratio of these two peaks). This suggested that CBC might be involved in E complex assembly. However, the $50 \%$ reduction did not correlate quantitatively with the strong inhibition of splicing seen in depleted extracts ion the order of $80 \%-90 \%$; e.g., Fig. 1). Two explanations of these data seemed possible. First that CBC might affect the efficiency of more that one step in complex assembly, and second that the E complex observed in the depleted extract might not be identical to that in the control extract.

It has been shown that E-like complexes can form independently on RNAs containing only a 3' splice site or a 5' splice site (Michaud and Reed 1993). These are named the E $3^{\prime}$ and $E 5^{\prime}$ complexes, respectively. The former complex is enriched in U2AF, which binds to the polypyrimidine tract, and the latter is enriched in $\mathbf{U} 1$ snRNP, however, both have a similar composition to the E complex formed on complete pre-mRNAs. To determine how the assembly of E3' or E5' complexes would be affected in CBC-depleted extracts, RNAs containing only a $3^{\prime}$ splice sitc $\left(A d 3^{\prime}\right)$ or a $5^{\prime}$ splice site $\left(A d 5^{\prime}\right)$ were transcribcd and used in complex assembly reactions. Analysis of E3' complex assembly in depleted versus mock-depleted extracts \{Fig. 2B\} showed a similar profile to that observed in the complete $\mathrm{E}$ complex assembly reaction on the entire pre-mRNA. E3' complex assembly as again inhibited to $\sim 50 \%$ compared with the mockdepleted control reaction. In contrast, the amount of E5' complex assembled was severly reduced compared to the control reaction (Fig. 2C). Although the small quantity of E5' complex remaining in the depleted extract makes accurate quantitation difficult, the level of inhibition of E5' complex formation was measured to be $-75 \%-80 \%$ in several experiments. This level of inhibition could account for most, if not all, of the splicing defect observed in depleted extracts. In summary, interations involving factors interacting with the $5^{\prime}$ splice site are more affected by $\mathrm{CBC}$ depletion than those at the $3^{\prime}$ splice site. This, together with the similar quantitative reduction in $\mathrm{E}$ complex formation seen in Figure 2, $\mathrm{A}$ and $B$, suggests that the complex seen in Figure $2 \mathrm{~A}$ probably corresponds to E3' rather than to complete E complex, and the relatively small reduction in this complex indicates that depletion of CBC has only a minor effect on the association of most components of $E$ complex with the pre-mRNA. These results focus the role of CBC on the $5^{\prime}$ end of the intron, and thus on the interaction between Ul snRNP and the 5' splice site.

$C B C$ is required for efficient $5^{\prime}$ splice-site $U 1$ sn RNP interaction

To address more directly whether CBC was required for the efficient association of Ul snRNP with the $5^{\prime}$ splice 
Downloaded from genesdev.cshlp.org on April 26, 2023 - Published by Cold Spring Harbor Laboratory Press

Lewis et al.

A
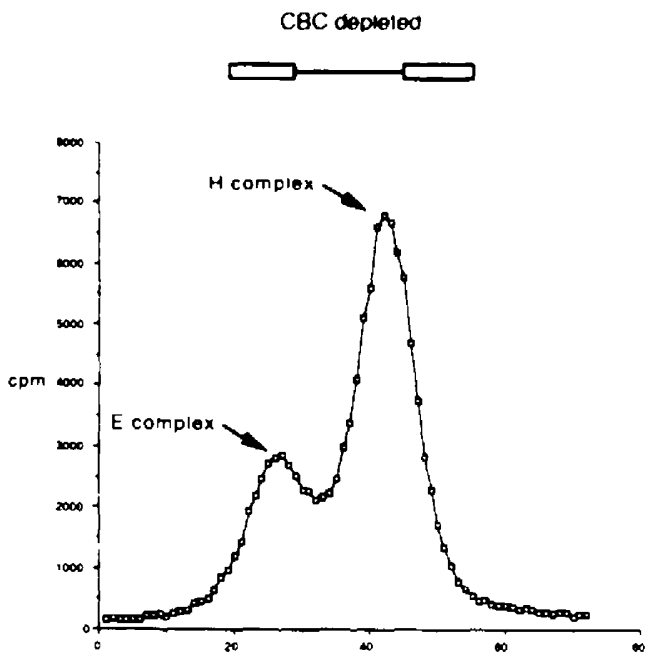

Fraction number

B
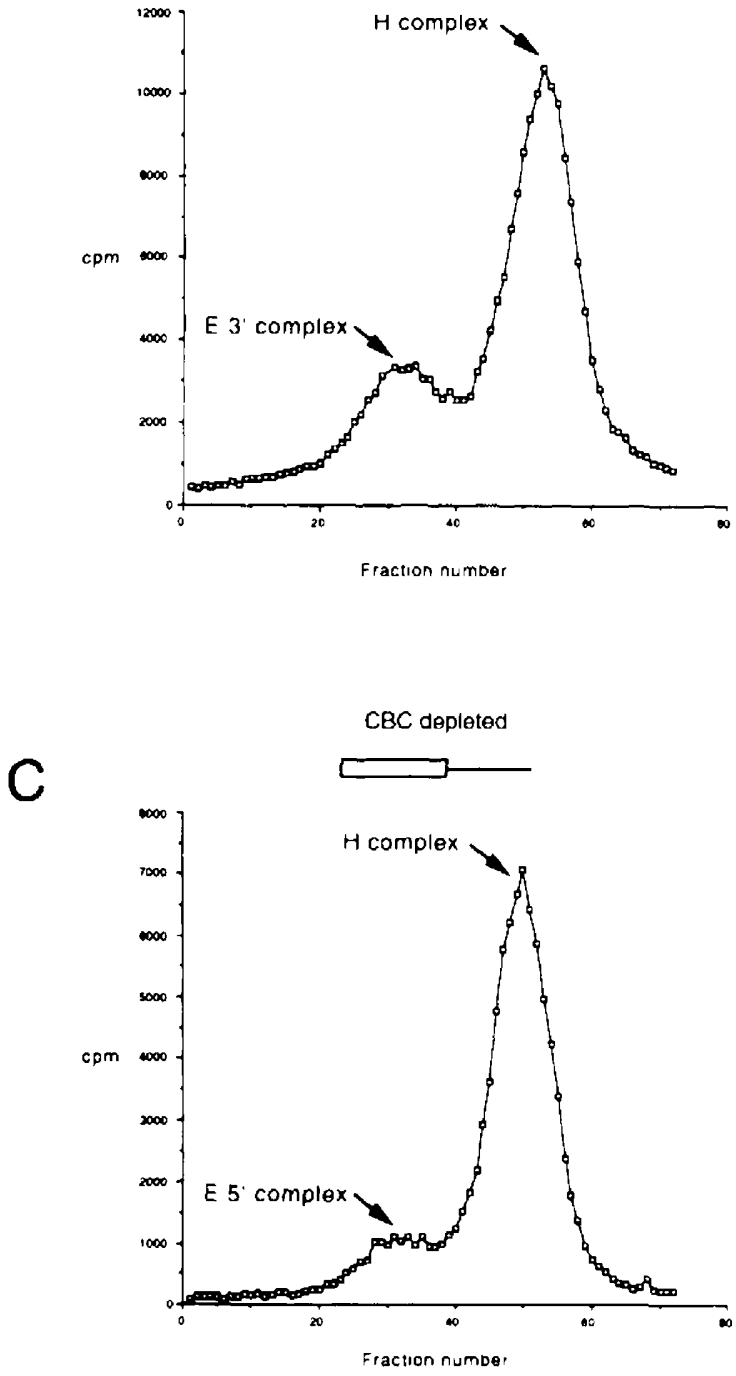
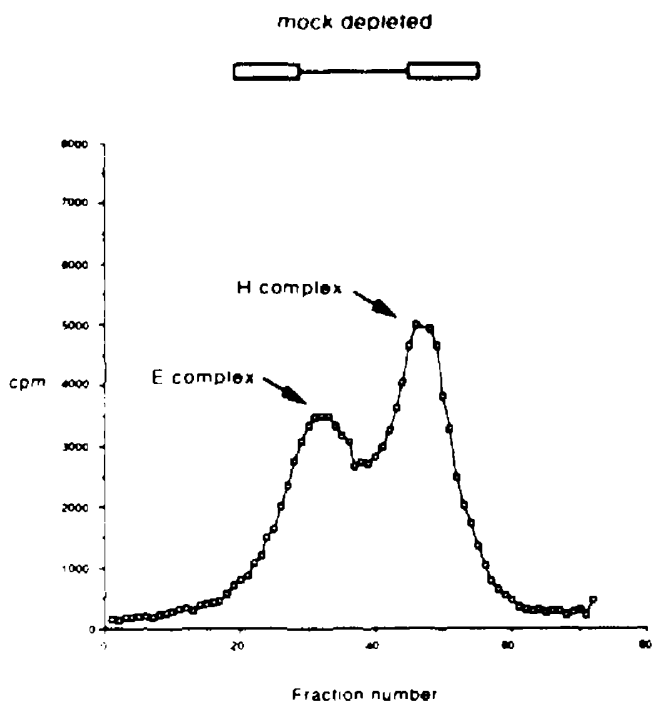

$$
\text { mock depleted }
$$

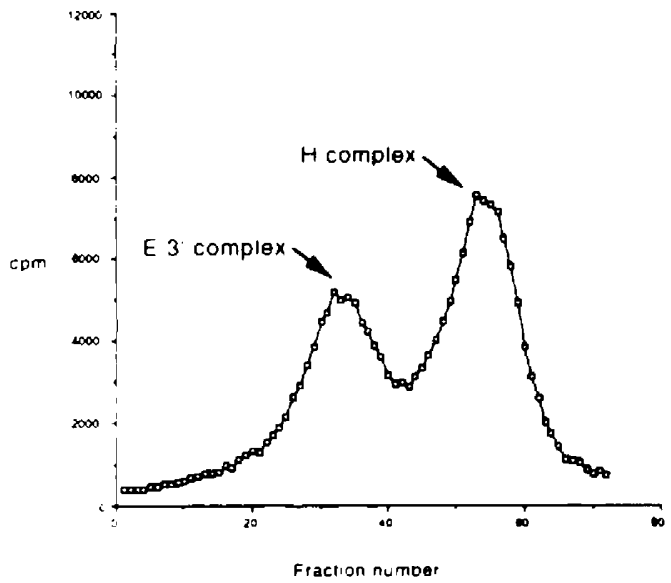

$$
\text { mock depleted }
$$

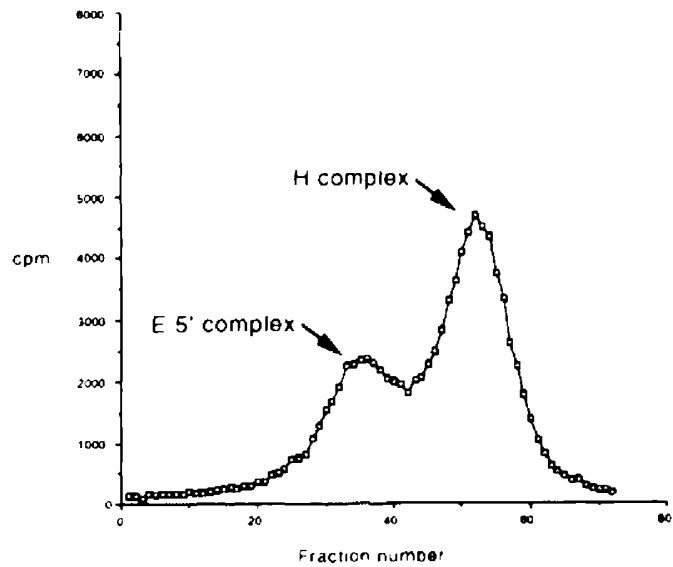

Figure 2. (See facing page for legend.|

1686

GENES \& DEVELOPMENT 
site, a series of psoralen cross-linking experiments were undertaken. Either the full length Adl pre-mRNA or the 5' half of the Ad1 pre-mRNA (Ad5') were used as substrates. Similar results were obtained with either substrate (Fig. 3, A, lanes 5-8, and B, lanes 1-4), but because intramolecular cross-links in the full-length pre-mRNA led to the production of a smear of cross-linked products that ran close to the U1 snRNA-pre-mRNA species (Fig. 3B|, mainly the Ad5' data are shown. As a control RNA, we used the $5^{\prime}$ half of a mutant precursor RNA (CX5'), which contains a $G \rightarrow$ A mutation at intron position 5 of the 5 ' splice site that effectively inhibits Ul snRNP binding and splicing (Hamm and Mattaj 1990). RNAs were capped in vitro with either $\mathrm{m}^{7} \mathrm{GpppG}$ or ApppG for Ad5' or $\mathrm{m}^{7} \mathrm{GpppG}$ for CX5'. Reaction conditions were the same as used to analyze E complex formation.

One major psoralen cross-link species (labeled X in Fig. $3 \mathrm{~A}$, lane 5) was observed when the $\mathrm{m}^{7} \mathrm{GpppG}$-capped wild-type substrate was used. This cross-link was dependent on the presence of psoralen in the reaction mixture and UV irradiation (data not shown). That its formation was attributable to a U1 snRNA-5' splice site interaction was demonstrated by two experiments. First, RNase $\mathrm{H}$ directed cleavage, using an oligonucleotide complementary to Ul snRNA, efficiently destroyed the crosslinked product (Fig. 3A, lane 6); and second, the Ul snRNA cross-link to the $5^{\prime}$ splice site was abolished when the $5^{\prime}$ splice site CX mutant RNA was utilized (Fig. 3A, lanes $1-4$ ).

The efficiency of $\mathrm{Ul}$ snRNA cross-linking to $\mathrm{m}^{7} \mathrm{G}$ Adl was greatly reduced in CBC-depleted extract (Fig. 3A, lane 71. Quantitation of this and three other independent experiments based on measurement of the amount of cross-linked species in relation to total RNA showed that the Ul snRNA cross-link was reduced by $\sim 80 \%-85 \%$ in depleted extracts compared to the mockdepleted controls. Similar results were obtained with the full-length precursor. The effect of CBC depletion with this substrate in the presence and absence of the Ulcomplementary oligonucleotide are shown (Fig. 3B, lanes 1-4). Again, $X$ is used to indicate the specific crosslinked product.

Interestingly, when the Ad5' precursor with the wildtype 5' splice site sequence but carrying an ApppG cap structure was used as a substrate, it cross-linked to U1 snRNA with an efficiency similar to that seen when $\mathrm{m}^{7}$ GpppG-capped Ad5' RNA was cross-linked in CBCdepleted extracts (Fig. 3A, cf. lanes 7 and 9). The level of cross-linking to the ApppG-capped substrate was not detectably reduced further by CBC depletion (lane 11). The degree of inhibition of cross-linking in lanes 9 and 11 compared to the control reaction in lane 5 was $\sim 80 \%$ in both cases. In summary, these results show directly that CBC depletion causes a large reduction in U1 snRNA cross-linking to the 5 ' splice site, and that this reduction can be mimicked by using an RNA carrying a cap structure that does not efficiently interact with $\mathrm{CBC}$. Note that the reduction in $\mathrm{Ul}$ cross-linking is similar for both the truncated and full length pre-mRNA substrates (Fig. 3 , A, lanes 5,7 , and B, lanes 1,3$\}$. Thus, despite that fact that the full length substrate still forms an E-like presplicing complex (see above), the Ul snRNA in this complex (Michaud and Reed 1993) does not associate normally with the $5^{\prime}$ splice site. This indicates that although $C B C$ depletion only has a small effect on the association of most $E$ complex components with the premRNA, its absence prevents normal Ul snRNP-5' splice site interaction.

To determine whether $\mathrm{rCBC}$ could reverse the defect in Ul snRNP association, $\mathrm{rCBC}$ was added to depleted or, as a control, mock-depleted extract. Although the levels of cross-linking in mock depleted controls (Fig. 3C, lanes 1,2 / were unaffected, $\mathrm{rCBC}$ efficiently restored the $U 1$ snRNA cross-link in depleted extracts /cf. lanes 3 and 4). The magnitude of the reduction in Ul snRNA crosslinking following $\mathrm{CBC}$ depletion, and its restoration by rCBC, suggest that most, if not all, of the splicing defect in $\mathrm{CBC}$ depleted extracts can be attributed to the reduction in Ul snRNP binding to the 5 ' splice site.

\section{$S R$ proteins can overcome the effects \\ of $C B C$ depletion but do not mediate the CBC effect on $U 1$ snRNP}

Aside from CBC, the SR protein family of splicing factors has been shown to play a role in UI snRNP recruitment to the 5' splice site (Fu and Maniatis 1992; Fu 1993; Kohtz et al. 1994; Jamison et al. 1995; see Discussion). We therefore examined the effects of adding SR proteins to $\mathrm{CBC}$-depleted extract. The addition of increasing quantities of a purified mixture of SR proteins / which do not contain significant quantities of $\mathrm{CBC}_{\text {; data not }}$ shownl to CBC-depleted or mock-depleted extract increased the splicing efficiency of both extracts to a point where no difference between the two extracts could be seen (Fig. 4A, lanes 3-10). Addition of CBC to SR proteinsupplemented splicing reactions such as those in lanes 7-10 had no detectable further effect on splicing efficiency |data not shown/. Cross-linking of Ul snRNP to the Ad5' substrate was measured in parallel, and also increased differentially in both depleted and mock-depleted extracts to a level where both extracts exhibited similar levels of the cross-linked product (Fig. 4B, lanes $3-10$ ). These results were consistent with two possibilities. First, SR proteins might mediate the effect of $C B C$ on Ul snRNP-5' splice site interaction. In this case, addition of excess SR proteins would have obviated the need for $C B C$. The second possibility was that SR proteins and $C B C$ affect U1 snRNP-5' splice site interaction

Figure 2. $C B C$ depletion affects early steps of presplicing complex assembly. The effect of CBC depletion was assayed on $E|A|, E 3$ ' $(B)$, and $\left.5^{\prime}, C\right)$ complex formation in splicing reactions lacking $A$ TP and $\mathrm{MgCl}_{2}$ usıng either $\mathrm{CBC}$-depleted or mock-depleted extracts. The complexes were allowed to form for $15 \mathrm{~min}$ and were then fractionated by gel filtration. A representative result is shown from each class. 
A

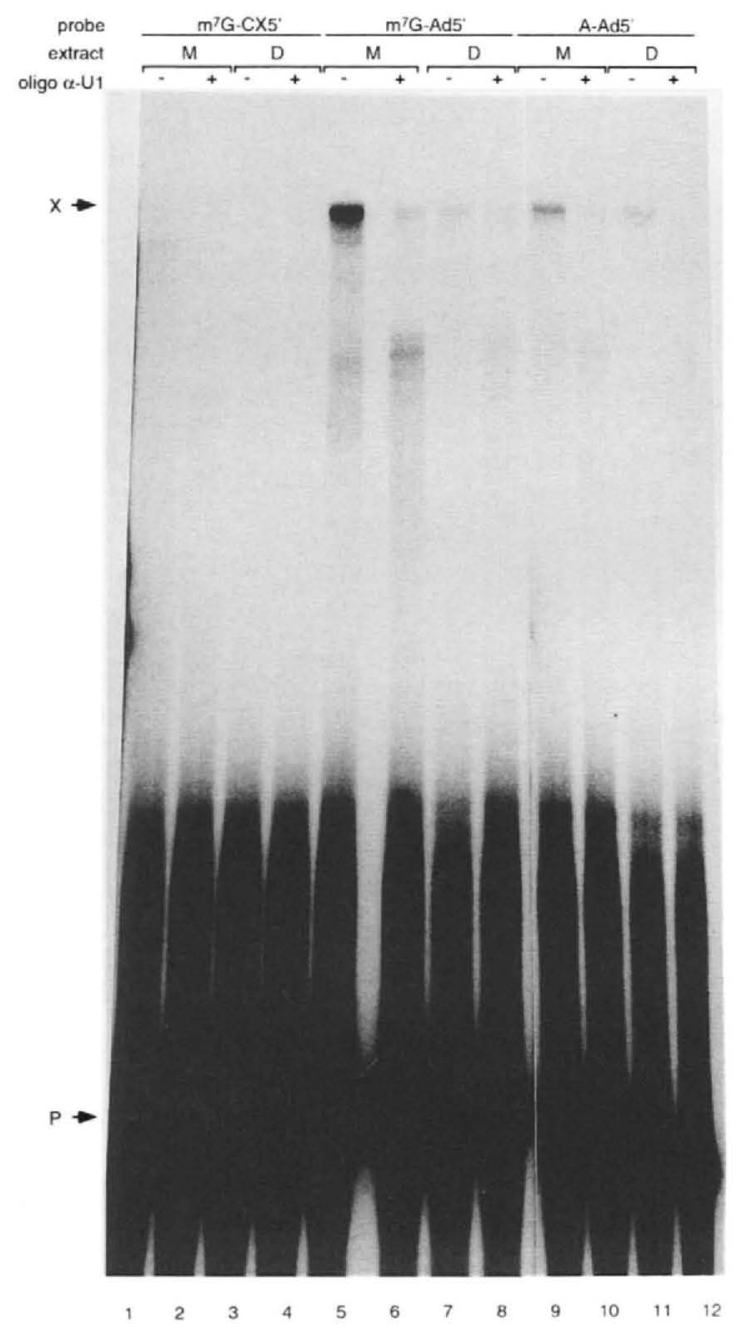

B

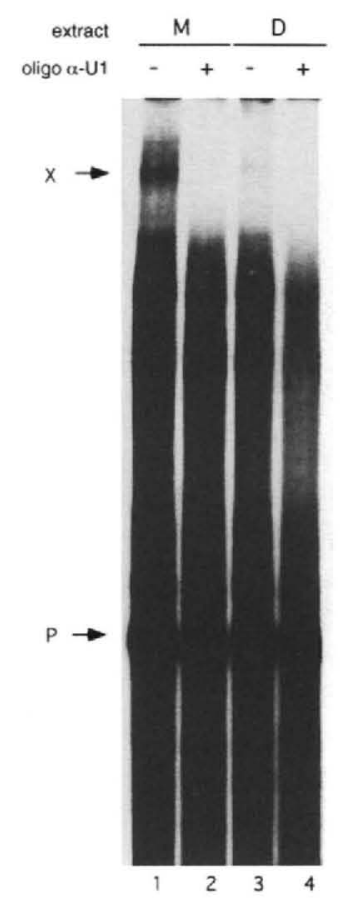

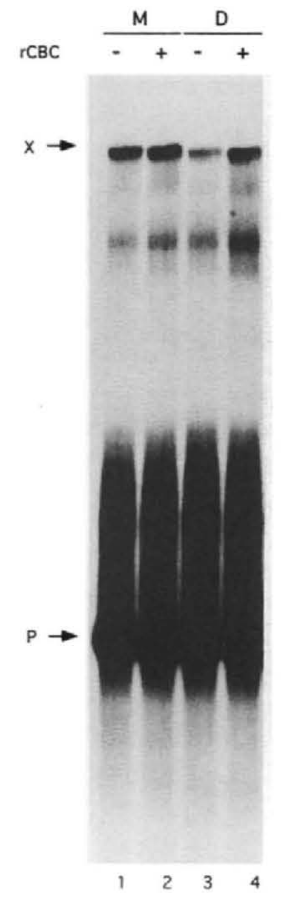

Figure 3. $\mathrm{CBC}$ is required for the efficient cross-linking of U1 snRNA to the 5' splice site. (A) Splicing reactions were assembled under the same conditions used for E complex assembly using $\mathrm{m}^{7} \mathrm{GpppG}$-capped CX5' (lanes 1-4) $\mathrm{m}^{7} \mathrm{GpppG}$-capped Ad5' (lanes 5-8) and ApppG-capped Ad5' (lanes 9-12) in either depleted (D) or mock-depleted (M) extracts. After cross-linking the samples were digested with RNase $\mathrm{H}$ in the presence of either buffer $(-)$ or an oligonucleotide complementary to U1 snRNA $|+|$. Cross-linked products $\mid \mathrm{x})$ were resolved from non-cross-linked probe (P) by $6 \%$ denaturing PAGE. $(B)$ Reactions as described in $A$, lanes $5-8$, except that the full length pBSAdl substrate was used. $(C)$ rCBC restores Ul snRNA cross-linking to the 5 splice site in depleted extract. rCBC was added to either depleted or mock-depleted extract $|+|$ during the preincubation. As a control, buffer was added to both reactions $(-\mid)$

by separate mechanisms. To distinguish between the two, we made use of highly purified Ul snRNP, recombinant CBC and purified SR proteins and tested their activity in the U1 snRNP cross-linking assay.

The amount of Ul snRNA cross-linked to the Ad5' substrate was measured over a range of $U 1$ snRNP concentrations (Fig. 5A, lanes 1-4). Addition of CBC to these reactions was without effect on the efficiency of crosslinking (Fig. 5B, lanes 5-8) indicating that the effect of CBC on U1 snRNP-5' splice site interaction requires mediating factors lacking from this purified system. To test whether these factors were in the SR protein prepa- ration, we added $S R$ proteins to the reactions. Over a wide range of $U 1$ snRNP, CBC and SR protein concentrations (Fig. 5B, lanes 1-4; and data not shown) we observed that whereas SR proteins increase Ul snRNP-5' splice site cross-linking, the addition of CBC to the mixture was without effect. In conclusion, the effect of $\mathrm{CBC}$ on Ul snRNP binding to the $5^{\prime}$ splice site is not observed when only these components are present, pointing to the existence of an additional factor required for this step. Although SR proteins can also, as previously demonstrated, increase Ul snRNP-5' splice site interaction, they cannot mediate the CBC effect. 
A

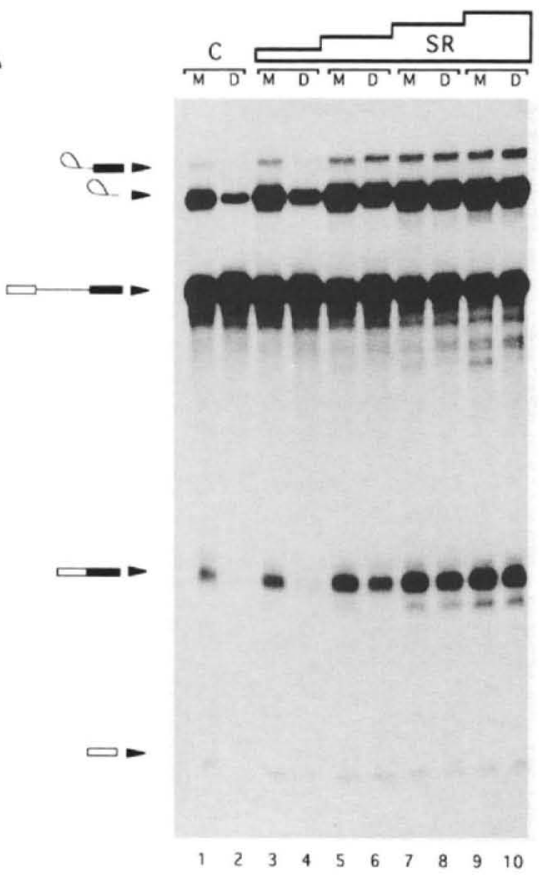

B

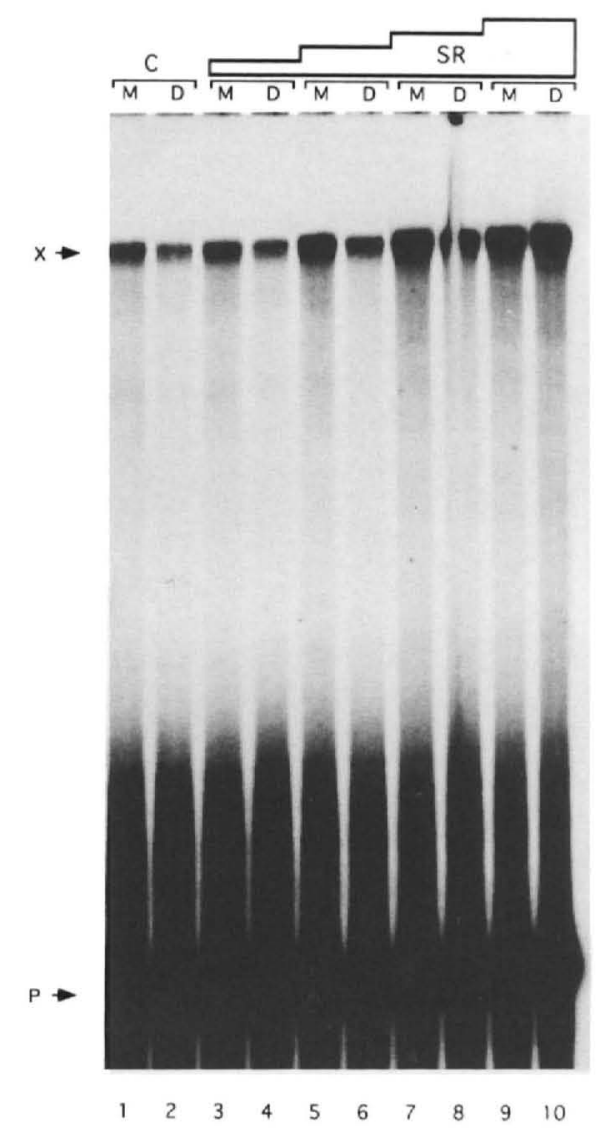

Figure 4. SR proteins restore splicing to a CBC-depleted extract by recruiting U1 snRNP to the $5^{\prime}$ splice site. $(A)$ Increasing amounts of SR proteins $(0.7 \mu \mathrm{g}$, lanes 3 and $4 ; 1.5 \mu \mathrm{g}$, lanes 5 and $6 ; 3 \mu \mathrm{g}$, lanes 7 and $8 ; 6 \mu \mathrm{g}$, lanes 9 and 10$)$ were added to either depleted (D) or mock-depleted (M) extracts. In the control reactions $(\mathrm{C})$, buffer was added. The splicing reactions were incubated for $2 \mathrm{hr}$, and RNA was recovered and products resolved by denaturing PAGE. $|B|$ Reactions were set up as for $A$ above, with the exception that no ATP or creatine phosphate was added and $\mathrm{m}^{7} \mathrm{GpppG}$-capped $\mathrm{Ad} 5$ ' was used as a substrate. The reactions were incubated for $15 \mathrm{~min}$ and then cross-linked (see Materials and methods). RNAs were recovered and resolved by denaturing PAGE.

\section{CBC facilitates splicing of cap-proximal introns}

Having demonstrated that $\mathrm{CBC}$ exerts its influence via an effect on Ul snRNP-5' splice site interaction, we wished to examine whether this effect was in some way position dependent. Previous studies in which the splicing of precursors containing two introns and carrying either an $\mathrm{m}^{7} \mathrm{GpppG}$ or an ApppG cap structure had led to the conclusion that the effect of the cap structure was limited to the cap proximal intron (Ohno et al. 1987; Inoue et al. 1989). However, the basis for this effect was not clear. For example, it was possible to imagine that either the distance along the RNA between the cap structure and the distal 5' splice site, or the sequence context of the proximal versus the distal $5^{\prime}$ splice site, could have led to the difference observed.

To investigate this, we contructed a hybrid double intron pre-mRNA called 004Ad. This contained the fourth intron of the Xenopus ribosomal protein Lla gene (Loreni et al. 1985) at a cap proximal position and the Ad1 intron cap distal (see Fig. 6A). Uniformly labeled 004Ad pre-mRNAs were synthesized in vitro, primed with $\mathrm{m}^{7} \mathrm{GpppG}$. Splicing of both the single Adl intron (Fig. 6B, lanes 1,2), as previously shown, and the 004 intron (lanes 3,4) was sensitive to CBC depletion. Quantitation of the level of inhibition showed it to be reproducibly between $80 \%$ and $90 \%$ for both introns. The 004Ad pre-mRNA was efficiently spliced in mock-depleted extracts (Fig. 6B, lane 5, the positions of products and intermediates are shown/. In CBC-depleted extracts there was a reduction in the level of splicing of the cap proximal 004 intron similar to that observed with the single intron constructs but much less effect on the cap distal adenovirus intron [(Fig. 6B, lane 6). Note that the $3^{\prime}$ end of this precursor is not identical to that of the single Adl pre-mRNA, and thus the size of the Adl intron-containing lariat intermediate is altered.] This resulted in an accumulation of partially spliced premRNAs containing the cap proximal intron. The inhibition can be observed most clearly by comparing the levels of the 004 intron product in the mock-depleted and depleted extracts (lanes 5,6). Quantitation of the efficiency of splicing showed that the cap proximal intron 
A

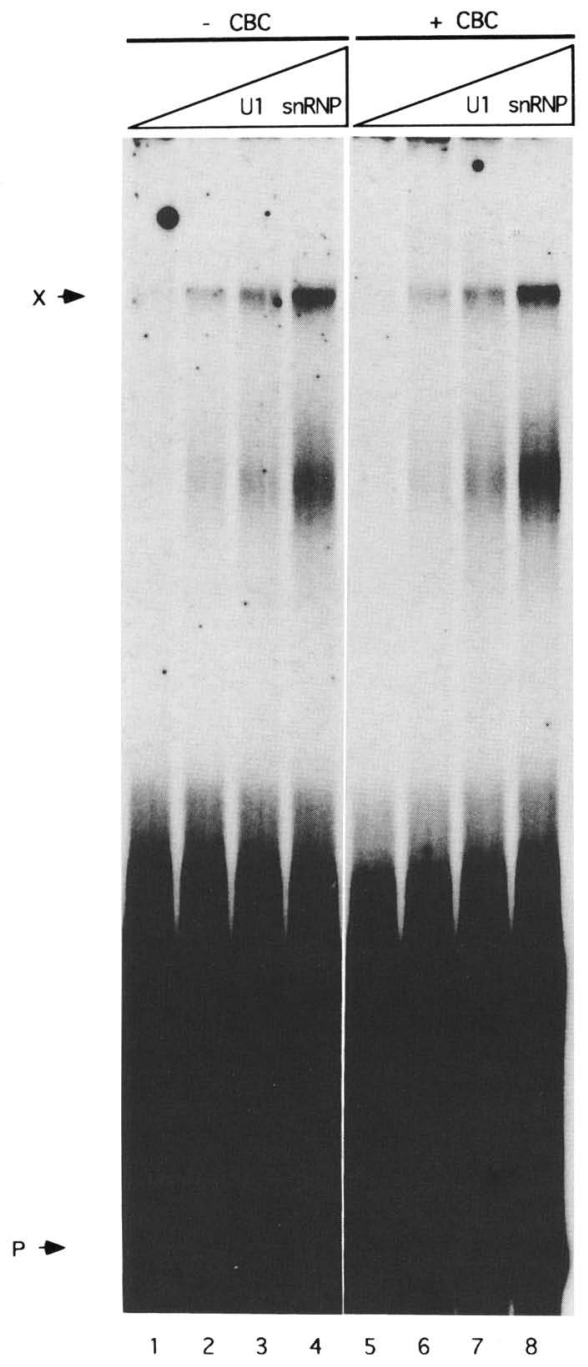

B

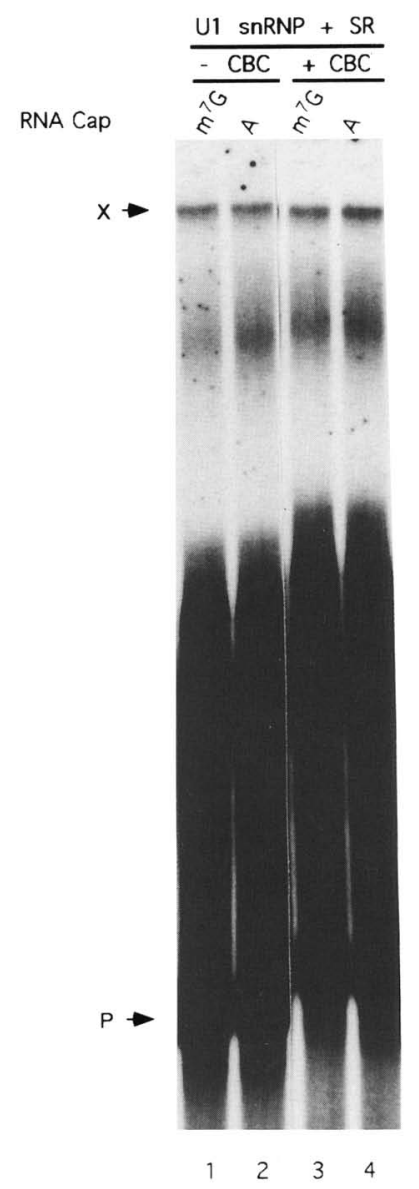

Figure 5. A mixture of $\mathrm{rCBC}, \mathrm{U} 1 \mathrm{snRNP}$, and SR proteins does not reconstitute cap-dependent association of U1 snRNP with the $5^{\circ}$ splice site. (A) Increasing amounts of purified U1 snRNP $\{30 \mathrm{ng}$, lanes 1 and $5 ; 62 \mathrm{ng}$, lanes 2 and $6 ; 125 \mathrm{ng}$, lanes 3 and 7; $250 \mathrm{ng}$, lanes 4 and 8$\}$ was incubated with $\mathrm{m}^{7} \mathrm{G}$-capped $\mathrm{Ad} 5^{\prime}$ in the absence or presence of a constant amount of rCBC. The reactions were irradiated under standard conditions, and the cross-linked products resolved by $6 \%$ denaturing PAGE. $\{B\}$ An SR protein-enriched fraction was assayed for its ability to stimulate U1 association with the $5^{\prime}$ splice site. A constant amount of Ul snRNP and SR protein fraction was added to either ApppG-capped (lanes 2,4) or $\mathrm{m}^{7} \mathrm{GpppG}$-capped Ad5' (lanes 1,3) either in the absence (lanes 1,2) or the presence (lanes 2,4 ) of $\mathrm{rCBC}$. The reactions were incubated, and UV cross-linked products resolved by $6 \%$ denaturing PAGE (see Materials and methods).

was inhibited to levels comparable to that of the single intron, whereas the inhibition of splicing of the cap distal intron varied between $20 \%$ and $30 \%$. This demonstrated that the cap dependence for efficient splicing of a cap-proximal intron (Ohno et al. 1987; Inoue et al. 1989) was mediated by the CBC.

To differentiate between various possiblilities for the insensitivity of the splicing of the more distal intron to $\mathrm{CBC}$ depletion, we created a series of mutant versions of the 004Ad construct, containing mutations at the $5^{\prime}$ splice site $\left(\Delta 5^{\prime}\right.$ 'ss), 3' splice site ( $\Delta 3^{\prime}$ 'ss), or the polypyrimidine tract $(\Delta P T)$ of the 004 intron (Fig. $6 \mathrm{~A})$. A second set of double mutants was then constructed where the $\Delta 5^{\prime}$ ss mutation was combined with the $\Delta 3{ }^{\prime}$ ss or $\Delta \mathrm{PT}$ mutations. These constructs were then transcribed and assayed for their ability to splice in mock-depleted or depleted extract. Mutation of the 5' splice site inhibited splicing of the cap proximal 004 intron but did not significantly affect the level of splicing of the downstream intron (Fig. 6C, lane 7). The level of Ad intron splicing from this mutant pre-mRNA in depleted extract was not greatly reduced compared to the mock-depleted control reaction (cf. lanes 7 and 8 ). Splicing of the $\Delta \mathrm{PT}$ or $\Delta 3^{\prime}$ ss pre-mRNAs was reasonably efficient in mock-depleted extracts (Fig. 6C, lanes 13,15) giving rise mainly to products that resulted from the skipping of exon 2 and ligation exons of 1 and 3 to produce the mature message. The resulting lariat product and lariat-exon intermedi- 
A

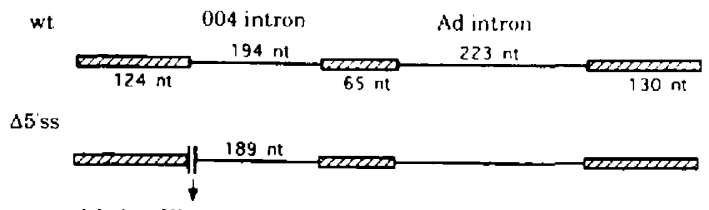

$\triangle \mathrm{PT}$

deletion: CUAAAGGUABALC

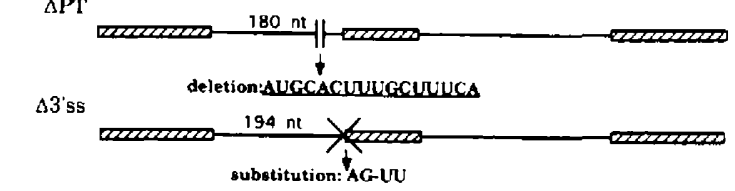

$\triangle 5^{\prime} \mathrm{s} \Delta \triangle \mathrm{PT}$

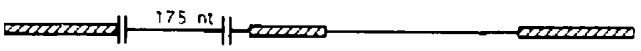

$\Delta 5 s s \Delta 3 s s$

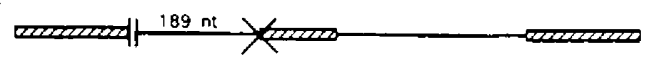

C
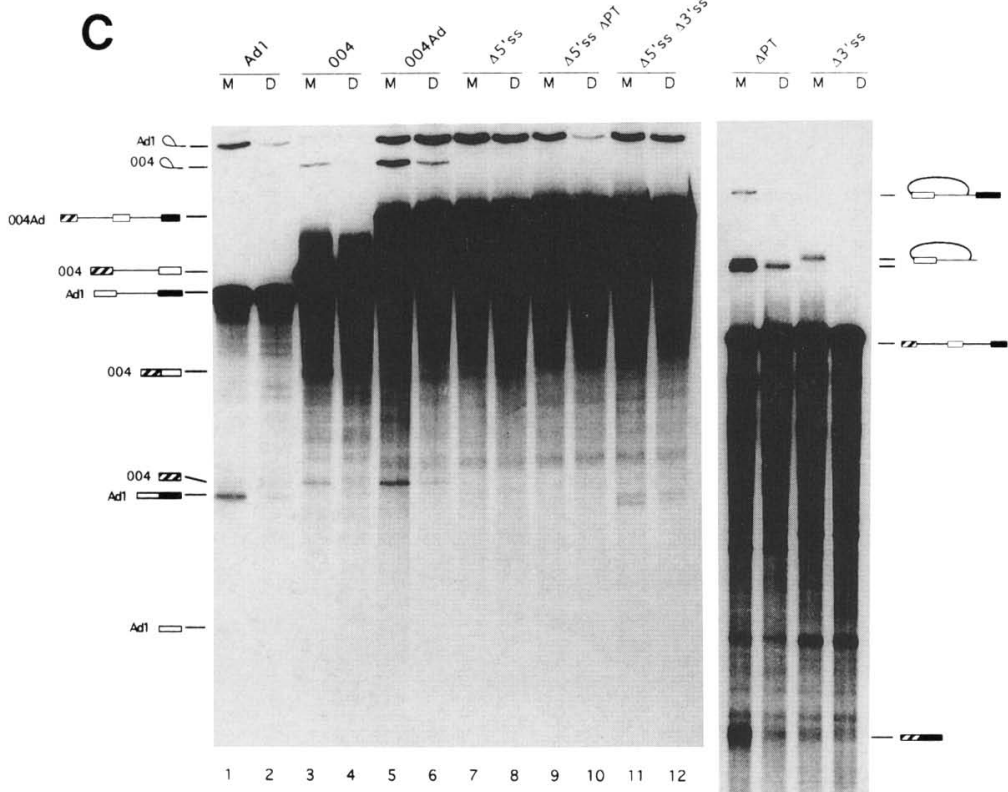

B

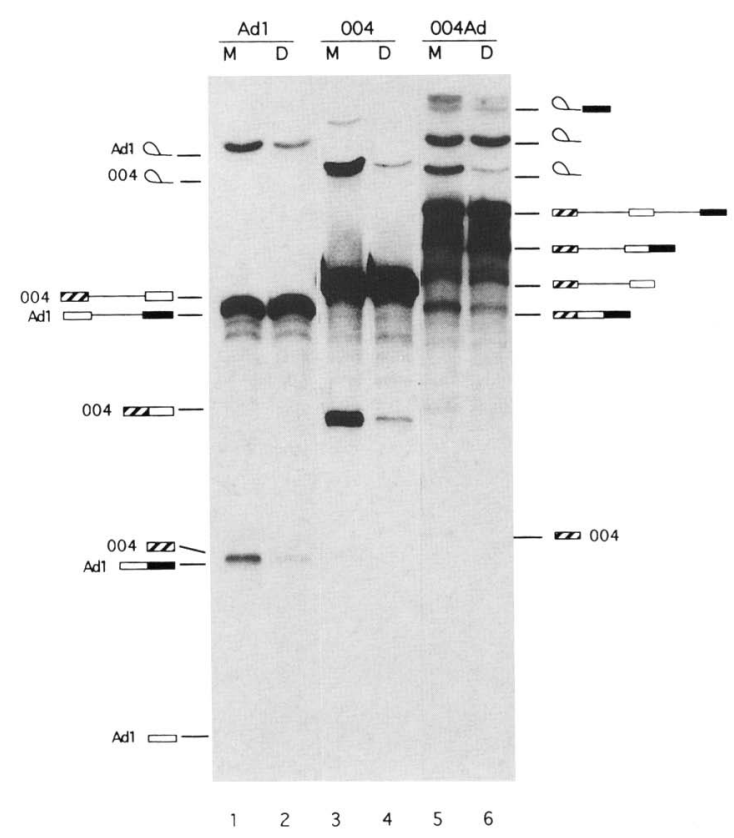

Figure 6. $\mathrm{CBC}$ is required for efficient splicing of the cap proximal intron. $(A)$ The double-intron constructs used are shown diagrammatically, together with the sequences mutated. $|B|$ Splicing in either mock-depleted extracts (M) or CBC-depleted extracts $\{\mathrm{D}$ ) of the following $\mathrm{m}$ 'GpppG-capped premRNAs; Adl |lanes 1.21, 004 |lanes 3.4|, and 004Ad |lanes 5.61. Splicing products were resolved on a $15 \%$ denaturing urea-polyacrylamide gel. The splicing products and intermediates are cartooned. (C) The polypyrimidine tract ( $\mathrm{SPT})$ insulates the cap distal intron from the effects of $C B C$ depletion. The premRNAs were synthesized with a $m^{7} \mathrm{GpppG}$ cap and spliced in CBC-depleted extract (D) or mock-depleted extract (M). 004Ad (lanes 5.6) is the wild-type double intron pre-mRNA, mutations at the 5 ' splice site $\left(\Delta 5^{\prime}\right.$ 'ss) (lanes 7.8$)$ has a deletion at the 5 ' splice site, $د \mathrm{PT}$ (lanes 13,14 ) has a deletion of polypyrimidine tract sequences, $\Delta 3$ 'ss (lanes 15,16 ) is an $\mathrm{AG} \rightarrow \mathrm{UU}$ mutant at the $3^{\prime}$ splice site, and $\Delta 5^{\prime}$ ss $\Delta 3$ 'ss (lanes 9,10 ) and $\Delta 5^{\prime}$ ss $\Delta P T$ (lanes 11,12 ) combine these mutations. Splicing reactions were incubated for $90 \mathrm{~min}$, and the splicing products resolved on either a $15 \%$ or a $6 \%$ denaturing ureapolyacrylamide gel. 
ate contain the skipped exon. When assayed in depleted extracts both constructs behaved like the single-intron constructs, their splicing being inhibited by $-80 \%$ llanes $14,16)$. Thus, the effect of CBC on utilization of the proximal $5^{\prime}$ splice site was maintained even when this $5^{\prime}$ splice site was being joined to the distal $3^{\prime}$ splice site.

Next, the 5' splice site and $\Delta \mathrm{PT}$ or 13 'ss double mutant constructs were assayed in mock-depleted or CBCdepleted extracts. The $\Delta 5^{\prime}$ 'ss $\Delta 3^{\prime}$ 's construct showed only a minor difference in downstream exon splicing, depending on whether CBC as present or not $\mid$ Fig. 6C, lanes 11 , 12). In contrast, although the $\Delta 5$ 'ss $\triangle P T$ mutation allowed splicing of the adenovirus intron in mock-depleted extracts, this mutant was unable to splice efficiently in CBC-depleted extracts (lanes 9,10). The effect of the CBC on the efficiency of splicing, and thus presumably of Ul snRNP-5' splice site interaction, is therefore relatively insensitive to distance and to sequence context. Rather, an intact polypyrimidine tract in the cap-proximal intron appears to functionally substitute for $\mathrm{CBC}$ in stimulating the use of the cap-distal 5 ' splicc site.

$C B C$ is associated with the pre-mRNA during the splicing cycle

All of the above results are consistent with the function of CBC in splicing bcing at an early stage of the process. We wished to determine whether CBC was associated with the pre-mRNA only transiently early during splicing or was more stably associated with the spliceosome. Splicing reactions were therefore carried out in untreated splicing extracts and subjected to immunoprecipitation using either preimmune serum or anti-CBP80 serum (Fig. 7A). The anti-CBP80 serum specifically, although inefficiently, precipitated the pre-mRNA, the mature mRNA and the intermediates of splicing (lane 3). The lariat product however, which does not have a cap, was not precipitated at levels over those observed with preimmune serum (lane 2). This suggested that CBC might associate early with the pre-mRNA and remain bound throughout the splicing cycle. To obtain independent evidence for this, a second method of examining the interaction of $C B C$ before and during splicing was sought.

In recent years techniques of purifying splicing and presplicing complexes assembled on biotinylated premRNA by gel filtration and streptavidin affinity selection have been established and refined (Reed et al. 1988; Reed 1990; Bennet et al. 1992a, bl. Various pre-mRNA complexes have been defined in this way including the $\mathrm{H}$ complex (Bennet et al. 1992b), a nonspecific complex that forms immediately on addition of essentially any RNA to HeLa nuclear extract, the $E$ and $A$ complexes described above, and the B complex, or active spliceosome. To address the question of whether CBP80 and CBP20 were present in the two extreme cases, that is, the $\mathrm{H}$ and $\mathrm{B}$ complex fractions, streptavidin selection was carried out. Buffer conditions were chosen $(250 \mathrm{~mm}$ salt) so as to isolate only those proteins which were stably associated with the pre-mRNA in the B complex frac- tion, that is, the spliceosome associated proteins or SAPs (Bennet et al. 1992a). A large-scale splcing reaction was fractionated by gel filtration and the spliccosome fraction $(B)$ and $H$ complex identified. Selected proteins from the $\mathrm{H}$ or the $\mathrm{B}$ fraction were then resolved on an SDSPAGE gel (Fig. 7B) and either silver stained (left panel) or blotted to a nitrocellulose membrane. The blot was first probed with anti-CBP80 antiserum then stripped and probed with serum raised against CBP20. Both proteins are recognized by their respective antibodies in the $\mathrm{H}$ complex and also in the B complex (lanes labeled $\alpha$-CBP80 and $\alpha$-CBP20, respectivelyl. As can be seen in the silver-stained gel of the isolated fractions, which was run in parallel, the protein composition of the $B$ fraction is quite complex. However, the arrowed band that is an abundant consituent of both $\mathrm{H}$ and $\mathrm{B}$ complexes corresponds in mobility to CBP80 and is therefore likely to be CBP80. It was not possible to identify CBP20 in the silver-stained gel as several closely spaced bands migrate in this region of the gel. Control precipitations using nonbiotinylated pre-mRNA did not result in enrichment of either CBP80 or CBP2O in the bound fraction /data not shown). In conclusion, $\mathrm{CBC}$ appears to associate not only with the $\mathrm{H}$ complex but also to be stably associated with the B complex. Thus, $\mathrm{CBC}$ seems to associate with the pre-mRNA carly in splicing and to remain bound to the cap when the mature mRNA leaves the spliceosome.

\section{Discussion}

The mode of action of the nuclear CBC in stimulating pre-mRNA splicing has been investigated. CBC binds to capped RNAs in vitro in a way that is independent of the presence of splicing signals in the RNA (Izaurralde et al. 1992, 1994, 1995). Consistent with this, immunoprecipitation and purification of splicing complexes showed that CBC was associated with the $\mathrm{H}$ complex that forms immediately on adding a substrate pre-mRNA to nuclear extract in a way that is independent of ATP or of splicing signals on the RNA. CBC, however, does not dissociate when specific splicing complexes form, as it was also found stably associated with the intermediates of splicing in the B complex, or spliceosome, as well as with the mature mRNA.

In spite of this, the major, and perhaps only, detectable influence of $C B C$ on splicing is on the efficiency with which Ul snRNP interacts with the $5^{\prime}$ splice site in the E, or carly, splicing complex. Simply measuring E-like complex formation on a complete pre-mRNA showed only a twofold reduction upon CBC depletion. However, further analysis showed that whereas the formation of E3' complex (Michaud and Reed 1993) on the 3' portion of the intron was also not greatly affected by CBC depletion, the formation of the corresponding E5' complex (Michaud and Reed 1993) was reduced strongly. Further analysis of $E$ complexes formed either on an entire premRNA or on the $5^{\prime}$ fragment of the intron showed that even when E-like complexes were formed, Ul snRNP-5' splice site interaction did not occur efficiently in CBCdepleted extracts. Thus, CBC depletion clearly does not 
A

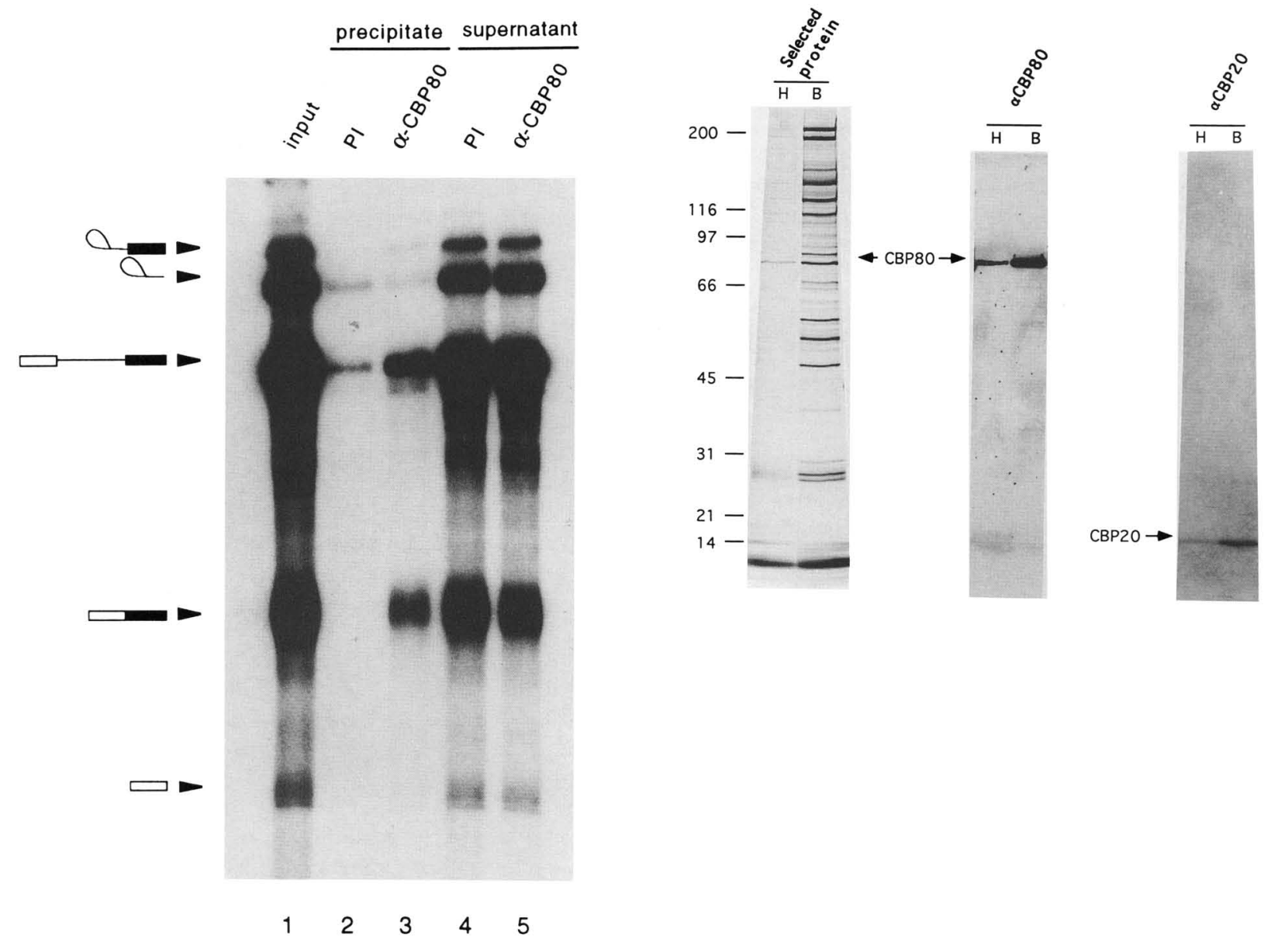

Figure 7. $C B C$ remains associated with the pre-mRNA throughout the splicing cycle. (A) Splicing intermediates and mRNA can be specifically precipitated by anti-CBP80 scrum. $m^{7} G$ pppG-capped Adl pre-mRNA was allowed to splice under standard conditions for 90 min and then immunoprecipitated using serum raised against CBP80 or preimmune serum. The immunoprecipitated products were recovered and resolved on a $10 \%$ denaturing urea-polyacrylamide gel. (Lane 1) Input reaction, (lanes 2.4) the precipitate and supernatant fractions for the preimmune serum; (lanes 3.5 the precipitate and supcrnatant fractions for the anti-CBP80 serum. $(B)$ CBC is stably associated with $B$ and $H$ complex. Spliceosomes were assembled on $\mathrm{m}^{7} \mathrm{GpppG}$-capped biotinylated Adl pre-mRNA and fractionated by gel filtration. The $\mathrm{B}$ and $\mathrm{H}$ fractions were selected in $2.50 \mathrm{~mm}$ salt, and the proteins resolved by $7.5 \%-20 \%$ gradient SDS-PAGE and silver stained. In parallel, samples were blotted to nitrocellulose, probed with anti-CBP80 serum, stripped, and probed with anti-CBP20 serum. The immunoreactive bands corresponding to $\mathrm{CBP} 80$ and $\mathrm{CBP} 20$ in the $\mathrm{H}$ and $\mathrm{B}$ complexes are marked as is the position of CBP80 in the selected proteins.

affect association of most of the components of $E$ complex with the pre-mRNA but has a specific effect on $U 1$ snRNP-5' splice site interaction within this complex.

Ul snRNP binding to the 5' colice site is a critical early step in intron recognition isee incroductory section). CBC interacts with pre-mRNAs rapidly after their addition to splicing extract (see above) and is associated with nascent transcripts in vivo (Visa et al. 1996). This and the other data in this manuscript support the hypothesis that $\mathrm{CBC}$ binding to a nascent transcript, which will be capped after it reaches a length of 20-30 nucleotides (Rasmussen and Lis 1993), can help to define an RNA as a potential splicing substrate. If there is a $5^{\prime}$ splice site in the transcript, CBC will help U1 snRNP to bind there, thereby increasing the probability that an intron in the nascent transcript will be recognized and defined. This could potentially represent the first specific step of pre-mRNA recognition in vivo.

The equivalent earliest step in spliceosome assembly in yeast occurs during formation of the commitment compiex (for review, see Rosbash and Séraphin 1991). Like mammalian E complexes, commitment complexes form in the absence of ATP and contain Ul snRNP and MUD2 in addition to the pre-mRNA, MUD2 being the probable yeast homolog of U2AF (Séraphin and Rosbash 1989; Abovich ct al. 1994). It is therefore of considerable interest that the yeast equivalent of CBP20 has been identified as the product of the MUD13 gene, a mutant 
form of which is synthetically lethal with a viable mutant allele of the gene encoding UI snRNA (Colot et al., this issue). Yeast extracts lacking the CBP20 homolog form commitment complexes with very low efficiency, and this phenotype can be reproduced in wild-type yeast extracts by using pre-mRNA substrates that are uncapped or by immunodepleting the yeast CBC (Colot et al., this issue; J. Lewis et al., unpubl.). This indicates that yeast and human $C B C$ carry out a similar, conserved function early in pre-mRNA recognition.

\section{Limitation of $C B C$ function to the cap-proximal intron}

The effect of the cap structure on intron removal has previously been reported to be limited to the cap-proximal intron in pre-mRNAs containing more than a single intron (Ohno et al. 1987; Inoue et al. 1989). It is demonstrated here that this effect of the cap structure is medi. ated by the $\mathrm{CBC}$. Extending the previous data, we were also able to demonstrate that $\mathrm{CBC}$-independent splicing of the cap-distal intron was conferred by the polypyrimidine tract of the cap-proximal intron. When both the $5^{\prime}$ splice site and the polypyrimidine tract of the cap-proximal intron were mutant, the cap-distal intron became $\mathrm{CBC}$ dependent, demonstrating that neither the distance from the cap nor the sequence context of the distal intron were important for its CBC independence. Interestingly, when only the 3 ' splice site or the polypyrimidine tract of the proximal intron were mutant, major products of splicing that involved exon skipping were seen, that is, splicing from the cap-proximal 5' splice site to the cap distal $3^{\prime}$ splice site. These splicing events were again $\mathrm{CBC}$-dependent. In total these results support the conclusion that it is the cap-proximal $5^{\prime}$ splice site that is the target of CBC function, and that this interaction does not depend on a strict spacing between the cap and the affected 5' splice site. Moreover, they raise the possibility that the effect of CBC may be analogous to the effect, across the exon, of the polypyrimidine tract on the next downstream 5 ' splice site.

\section{$C B C$ and exon definition}

Both of these conclusions about the function of $\mathrm{CBC}$ in splicing fit very nicely into the model of splice site recognition that has been called exon definition (Robberson et al. 1990). The model proposes, and is supported by evidence which shows, that stabilizing interactions can occur across the exon between the upstrcam $3^{\prime}$ splice site and downstream 5' splice site (for review, see Berget 1995). In one of the best-studied cases, that of exon 4 of the rat preprotachykinin gene, there is evidence that $\mathrm{Ul}$ snRNP binding to the 5 ' splice site immediately downstream of exon 4, through an indirect mechanism, stimulates binding of U2AF to the polypyrimidine tract of the 3' splice site upstream of exon 4 (Hoffman and Grabowski 1992!.

One problem posed by exon definition is how the first and last exons in a pre-mRNA are defined. Evidence ex- ists that cleavage and polyadcnylation signals may increase the efficiency of recognition of the $3^{\prime}$-most intron (c.g., Niwa and Berget 1991; for review, see Berget 1995), although this effect is apparently not universal (Nesic et al. 1995). This presumably reflects direct or indirect interactions between components of the $3^{\prime}$ end formation and splicing machinerics analogous to those between splicing factors bound to sites flanking an exon discussed above. Clearly, the CBC-mediated stimulation of the binding of the cap-proximal 5' splice site by U1 snRNP provides a mechanism for efficient recognition of this splice site. Because it is likely that this is an early event in pre-mRNA packaging, it is also plausible that this unique interaction helps to define which is the cap-proximal $5^{\prime}$ splice site, and thus ensures that splice site pairing across the intron occurs in the correct register, resulting in accurate splice site definition along the entire length of the pre-mRNA transcript.

Which proteins might be involved in mediating the interactions between factors bound either to splice sites or to the extremities of a pre-mRNA? An extreme case of bridging interactions resulting in pairing between a $5^{\prime}$ and a $3^{\prime}$ splice site was reported recently /Chiara and Reed 19951. Here, interactions leading to trans-splicing between $5^{\prime}$ and $3^{\prime}$ 'splice sites located on two different RNAs was observed, provided that the $3^{\prime}$ splice site RNA also contained, downstream of the $3^{\prime}$ splice site, sequences encoding either a $5^{\prime}$ splice site or an exon enhancer (Chiara and Reed 1995). The exon enhancer used has previously been proposed to bind both to U1 snRNP and to other proteins (Watakabe et al. 1993; Tanaka et al. 19941. Analysis of diverse exon enhancers ie.g., Tian and Maniatis 1993; Heinrichs and Baker 1995) show that among the critical proteins that bind to these elements are members of the SR protein family. This and other data [Fu 1993; Kohtz et al. 1994; Jamison et al. 1995) suggest that $S R$ proteins play a role in the recognition of introns by helping to establish stable interactions between splicing factors like $U 1$ snRNP and U2AF and their recognition sequences on the pre-mRNA, as well as potentially, presumably at a later step, mediating interactions between these factors across the intron once they are bound to the 3' or 5' splice site.

How then might the CBC participate in facilitating the interaction between $\mathrm{Ul}$ snRNP and the $5^{\prime}$ splice site? Neither of the components of CBC, CBP80, or CBP20 (Izaurralde ct al. 1994, 1995) contain the dipeptide repeats that are characteristic of the SR protein family (e.g., Zahler et al. 1992), and thus CBC is perhaps unlikely to act directly on UI snRNP in the way proposed for some SR proteins (see, e.g., Fu and Maniatis 1992; Fu 1993; Kohtz et al. 1994; Jamison ct al. 1995). Although we observed a large decrease in Ul snRNP-5' splice site interaction in extracts depleted of $\mathrm{CBC}$, we were unable to see any positive effect on U1 snRNP-5' splice site cross-linking when utilizing highly purified U1 snRNP and recombinant $\mathrm{CBC}$. Addition of SK proteins to $\mathrm{CBC}$ depleted extract resulted in stimulation of splicing and of Ul snRNP-5' splice site interaction. However, in a highly purified reconstituted system SR protein addition 
had no effect on the dependence of $U 1$ snRNP $-5^{\prime}$ splice site interaction on $\mathrm{CBC}$. These results argue against $\mathrm{SR}$ proteins being the mediators of the $\mathrm{CBC}$ effect on $\mathrm{Ul}$ snRNP. In addition, other work (Colot et al., this issue; $J$. Lewis et al., unpubl.| shows that yeast CBC plays a similar role in commitment complex assembly to that of human $\mathrm{CBC}$ in $\mathrm{E}$ complex formation. Because no $\mathrm{SR}$ proteins have thus far been identified in yeast, the likelihood of their mediating the CBC effect in vertebrates is further reduced. Thus, although either readdition of $C B C$ or the addition of excess SR proteins to CBC depleted extracts could stimulate U1 snRNP-5' splice site inter. action, the mechanism of these effects is likely to be different isce also Fu 1993; Kohtz et al. 1994; Jamison et al. 1995). The factor or factors that mediate the interaction between $\mathrm{CBC}$ and the $\mathrm{Ul}$ snRNP remains to be identified. It is even possible that the effect of the CBC is an antirepression effect, in that it might help to hinder the action of factors whose binding to the pre-mRNA would have a negative influence on the subsequent interaction of Ul snRNP with pre-mRNA. Further study will be required to distinguish between these possibilities.

\section{The role of $C B C$ in nuclear export}

$\mathrm{CBC}$ remains associated with the cap throughout the splicing reaction and is released together with the mRNA. Studies on the nuclear export of RNA polymerase II transcripts have shown that CBC plays an important role in mediating $U$ snRNA nuclear export (Izaurralde et al. 19951. Although the cap structure does not have such a critical influence on mRNA export as it does on U snRNA export, the presence of a $5^{\prime}$ cap stimulates the kinetics of mRNA export by approximately twofold (Jarmolowski et al. 1994). Although the basis of this effect is unknown, CBC might, for example, increase the efficiency with which a messenger RNP docks with the nuclear pore in a specific orientation that is favorable for export. Data from Dancholt and co-workers have shown that in Chironomous tentans salivary gland cell nuclei, the Balbiani ring messenger RNP always docks with the nuclear pore complex $5^{\prime}$ end first and is translocated through the pore to the cytoplasm in a $5^{\prime} \rightarrow 3^{\prime}$ orientation (Mehlin et al. 1992, 1995). Recent data indicate that CBC is associated with Balbiani ring mRNPs during these docking and translocation steps (Visa et al. 1996), consistent with the hypothesis that $\mathrm{CBC}$ could have a role at these stages of RNA nuclear export.

\section{Materials and methods}

\section{DNA constructs}

The following pre-mRNA plasmids were used, transcribed by T3 RNA polymerase: pBSAdl (Konarska and Sharp 1987) linearized by SaulllA; Ad5' was made by cleaving pBSAdl with Fnu4HI; pAdlDHindIII was linearized by SauIIIA; pBSO04 iderived from the Xenopus L1a gene (Loreni et al. 1985 ) encompassing exons 4 and 5 was linearized by EcoRI; pBSO04Ad and

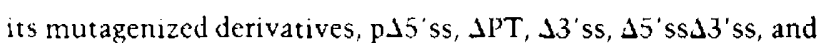
$\triangle I$ 'ss $د P T$ were linearized by EcoRI.

pBSO04Ad was constructed by cloning the Pvull-EcoRI fragment of pBSAd! into the pBS - vector /Stratagenel between the Smal and EcoRI sites. Then the BamHI fragment containing the Adl intron was recloned into the BamHI site of pBSO04. This double intron construct contains the 004 intron 1194 nucleotidesl at a cap-proximal position, the Adl intron 1223 nuclestides/ cap-distal and three exons: E1, E2, and E.3 $\mid 124,65$, and 1.30 nucleotides, respectively!. The derivatives of pBSO04Ad were created by site-directed mutagenesis. $\mathrm{p} 15^{\prime}$ ss has a deletion [GGTAA) at the 5 ' splice site of the 004 intron, $\mathrm{IPT}$ has a deletion (ATGCACTTTGCTTT) of sequences at and near the 004 polypyrimidine tract, and 13 'ss has the last two nucleotides of the 004 intron changed from AG to TT. The double mutants combine these changes.

FCX $\mid$ Hamm and Mattaj 1990!, which is a mutant derived trom pBSAdl, where position 5 of the intron is altered from $G$ to A, was linearized by SalilliA and transcribed by T7 RNA poly. merase.

\section{$C B C$ depleted extracts}

Fresh HcLa cells were purchased from the Compurer Cell Culture Centre |Mons, Belgium।. Nuclear splicing extracts were prepared essentially as described by Dignam et al. (1983). Extracts were depleted of CBC using anti-CBP80 serum coupled to Fast Flow I'rotein A 4 as described previously (Izaurralde et al. 1994 !.

\section{Splicing reactions}

Splicing reactions were in a final volume of $20 \mu \mathrm{l}$ as described in [zaurralde et al. \{1994|. Substrates were transcribed using T3 RNA polymerase. The reaction was preincubated in the absence of ATP, creatine phosphate, or pre-mRNA $13-5 \mathrm{ng}$ for single. intron constructs and $6-8 \mathrm{ng}$ for double-intron constructs| for 15 min at $30^{\circ} \mathrm{C}$. The splicing reaction was started by addition of these components and incubated for either 90 or $120 \mathrm{~min}$. The spliced products were recovered and resolved by $10 \%$ denaturing PAGE for the Adl pre-mRNA. The double-intron constructs were resolved by $15 \%$ denaturing PAGE or, in the case of $\triangle \mathrm{PT}$ and 13 'ss, by $6 \%$ denaturing PAGE.

\section{Recombinant $C B C$ and $C B P 20$ and gel mobility shift assay}

rCBC: was produced as described in Izaurralde et al. (1995), with the tollowing modification. Prior to elution with imidazole, the bound protein was washed in PGK buffer containing 0.05\% Triton X-100 then eluted with $500 \mathrm{~mm}$ imidazole in PGK buffer, $0.05 \%$ Triton $\mathrm{X} \cdot 100$. The peak fractions were dialysed against buffer $\mathrm{D} / 100 \mathrm{mM} \mathrm{KCl}, 20 \mathrm{~mm}$ Hepes at $\mathrm{pH} 7.9,0.2 \mathrm{~mm}$ EDTA, $20 \%$ glycerol, $1 \mathrm{mM}$ DTT. The gel mobility shift assay was as described previously (Izaurralde et al. 1992).

\section{Immunoprecipitation of splicing reactions}

Splicing reactions were incubated for $90 \mathrm{~min}$, then diluted 20 told in IPP2 $501250 \mathrm{~mm} \mathrm{NaCl}, 20 \mathrm{mM}$ Tris at $\mathrm{pH} 7.5,0.1 \%$ Triton $X-100$ l. This mixture was then divided into two aliquots and 10 $\mu l$ of either anti.CBP80 scrum or preimmune serum was added and incubated on ice for $1 \mathrm{hr}$. To this was added $40 \mu \mathrm{I}$ of a $50 \%$ suspension of protein A sepharose beads in IPP250 and the mixture was rotated at room temperature for $30 \mathrm{~min}$. The bound antibody complexes were then pelleted by centrifugation and washed three times with $1 \mathrm{ml}$ of IPP250. To extract the RNA, 
the pellets were digested in a final volume of $50 \mu \mathrm{l}$ of RNA extraction buffer containing $1 \mathrm{mg} / \mathrm{ml}$ of proteinase $\mathrm{K}$ and $1 \%$ SDS. Carrier tRNA $(2.5 \mu \mathrm{g})$ was added, and the mixture was phenol extracted and ethanol precipitated. In parallel, the RNA from the supernatant was recovered. The precipitated products and supernatants were then resolved by $10 \%$ denaturing PAGE.

\section{Purification of splicing complexes}

Purification of splicing complexes was carried out essentially as described by Reed (1990). An $11 \mathrm{ml}$ splicing reaction was assembled and aliquoted into $0.5-\mathrm{ml}$ fractions. These were incubated for $20 \mathrm{~min}$ at $30^{\circ} \mathrm{C}$ in the presence of biotinylated $\mathrm{m}^{7} \mathrm{GpppG}$-capped pre-mRNA $(\sim 30 \mu \mathrm{g})$. Under these conditions, the vast majority of assembled spliceosomes have not undergone the first step of splicing and are predominantly B splicing complexes as determined by native gel electrophoresis. The only modification to the published protocol was that $\mathrm{B}$ complexes were resolved from $\mathrm{H}$ complex by gel filtration on a Sephacryl S-500HR XK26/70 column (Pharmacia) at a flow rate of $0.4 \mathrm{ml} / \mathrm{min}$. Fractions $(1.6 \mathrm{ml})$ were collected and $1 / 16$ of each was counted by liquid scintilation. Peak fractions were pooled, and the salt concentration adjusted to $250 \mathrm{~mm}$ by addition of $5 \mathrm{M}$ $\mathrm{NaCl}$ prior to selection. Selected proteins were resolved by $7.5 \%-20 \%$ SDS-PAGE and silver stained (Wray et al. 1981 ).

\section{E complex analysis}

E, E5', and E3' complex analysis was performed essentially as described (Michaud and Reed 1991, 1993). Splicing reactions $(300 \mu l)$ werc set up using mock-depletcd or depleted extracts in the absence of ATP or creatine phosphate, and preincubated at $30^{\circ} \mathrm{C}$ for $20 \mathrm{~min}$ to deplete endogenous ATP. After the preincubation, the $\mathrm{m}^{7} \mathrm{GpppG}$-capped transcript $(30-50 \mathrm{ng})$ was added and incubated for an additonal $15 \mathrm{~min}$ to allow complex assem. bly. Complexes were then resolved by Sephacryl S-500HR gel filtration (XK16/70 Pharmacial at a flow ratc of $0.15 \mathrm{ml} / \mathrm{min}$, and $0.6-\mathrm{ml}$ fractions were collected and counted by liquid scintillation.

\section{Psoralen cross-linking and $R$ Nase $H$ digestion}

Reactions were assembled under conditions similar to those used for E complex assembly, cxcept that AMT-psoralen (HRI Associates| was added to a final concentration of $50 \mathrm{ng} / \mathrm{ml}$. Probes were in vitro transcribed under conditions that result in a high specific activity in the presence of $80 \mu \mathrm{Ci}$ of $\mid \alpha^{32}$ P|UTP (Wassarman and Steitz 1992), primed with either an $\mathrm{m}^{7} \mathrm{CpppG}$ or ApppG cap as indicated in the legend to Figure 3. The complexes were allowed to assemble for $15 \mathrm{~min}$, then the sam. ples were irradiated for $10 \mathrm{~min}$ at $360 \mathrm{~nm}$ in an HRI photocell that was precooled to $4^{\circ} \mathrm{C}$. After cross-linking, proteins were digested at $50^{\circ} \mathrm{C}$ for $20 \mathrm{~min}$ by addition of a proteinase $\mathrm{K} / \mathrm{SDS}$ mix. The samples were then extracted with phenol/chloroform $\{1: 1 \mathrm{vol} / \mathrm{vol}\}$ and ethanol precipitated. RNA pellets were either dissolved in formamide loading dye and heat denatured or dissolved in $4 \mu \mathrm{l}$ of TE for RNase $\mathrm{H}$ digestion. RNase $\mathrm{H}$ digestions were carried out for $60 \mathrm{~min}$ at $30^{\circ} \mathrm{C}$ in a final reaction of $10 \mu \mathrm{l}$ in a buffer containing $40 \mathrm{mM}$ Tris $(\mathrm{pH} 7.5), 50 \mathrm{mM} \mathrm{KCl}, 5 \mathrm{mM}$ $\mathrm{MgCl}_{2}, 2.5 \mathrm{mg}$ of tRNA, and 2 units of RNase $\mathrm{H}$ (GlBCO BRL). The anti-Ul snRNA oligonuclcotide was complimentary to nucleotides $64-75$ of the UI snRNA. After the digestion, reactions were phenol/chloroform extracted, ethanol precipitated, and dissolved in formamide loading dye. The cross-linked products were resolved from non-cross-linked probe on a $6 \%$ denaturing urea-polyacrylamide gel.

\section{Psoralen cross-linking in purified system}

For psoralen cross-linking by use of purified and recombinant components, the reactions were set up as described above with the following modifications. The salt concentration of the final reaction was adjusted to $35 \mathrm{~mm} \mathrm{KCl}$ by addition of buffer $\mathrm{D}$ (see abovel. Acctylated BSA (NEB) was added to a final concentration of $100 \mu \mathrm{g} / \mathrm{ml}$ to help stabilize the protein components. The reaction was assembled without the RNA and preincubated for $15 \mathrm{~min}$ at $30^{\circ} \mathrm{C}$. To start the reaction, RNA was added and incubated for an additional $15 \mathrm{~min}$. The samples were then irradiated in a HRI photocell that had been precooled to $4^{\circ} \mathrm{C}$ for $10 \mathrm{~min}$. The samples were then processed as described above.

\section{Purification of $U 1$ snRNP}

Ul snRNP was purified essentially as described by Bach et al. (1990). Nuclear splicing extracts were prepared (Dignam et al. 19831 and passed over an immobilized trimethyl guanosine antibody IOncogene Sciencel affinity column. The bound snRNPs were eluted overnight with methyl-7-guanosine (Sigma). The enriched snRNP eluate was then purified further using mono $Q$ chromatography with a linear 25 -ml gradient from $50-1000 \mathrm{~mm}$ $\mathrm{KCl}$ in mono Q buffer $20 \mathrm{~mm}$ Tris- $\mathrm{Cl}$ at $\mathrm{pH} 7.0,1.5 \mathrm{mM} \mathrm{MgCl}_{2}$, $0.5 \mathrm{~m} . \mathrm{M}$ DTT, $0.1 \mathrm{~mm}$ PMSFI. U1 snRNP was localized by Northern bloting, and the purity of the peak fractions checked by SDS-PAGE. Protein concentration was estimated using the BioRad Protein Assay.

\section{l'urification of SR proteins}

SR proteins were prepared from HeLa cells using the method described by Zahler et al. (1992) and were a kind gift from Drs. Cinzia Calvio and Angus Lamond (EMBL, Heidelberg, Germanyl.

\section{Acknowledgments}

We thank the members of our laboratory as well as David Tollervey and Bertrand Séraphin for comments on the manuscript, the EMBL photolaboratory for help in its preparation of the figures, and Nina Dathan for construction of several of the splicing substrate clones. We also thank Cinzia Calvio for providing SR proteins from HeLa cells. We particularly acknowledge Hildur Colot and Michael Rosbash for provision of unpublished information and useful suggestions. The work was partly supported by grants from the Human Fronticrs Science Programme and the European Union (EU) Human Capital and Mobility Programme (HCMP) to I.W. Mattai and an individual HCMP fellowship to I. Lewis.

The publication costs of this article were defrayed in part by payment of page charges. This article must therefore be hereby marked "advertisement" in accordance with 18 USC scction 1734 solely to indicate this fact.

\section{References}

Abovich, N., X.C. Liao, and M. Rosbash. 1994. The yeast MUD2 protein: An interaction with PRPll defines a bridge between commitment complexes and $\mathrm{U} 2$ addition. Genes \& Dev. 8: $84,3-854$.

Bach, M. P. Bringmann, and R. Lúhrmann. 1990. Purification of small nuclcar ribonucleoprotein particles with antibodies against modified nucleosides of small nuclear RNAs. Methods Enzymol. 181: 232-257.

Bennet, M., S. Michaud, J. Kingston, and R. Reed. 1992a. Protein components specifically associated with prespliceosome and spliceosome complexes. Genes \& Dev. 6: 1986-2000. 
Bennet, M., S. Piñol-Roma, D. Staknis, G. Dreyfuss, and R. Reed. 1992b. Differential binding of heterogenous nuclear ribonucleoproteins to mRNA precursors prior to spliceosome assembly in vitro. Mol. Cell. Biol. 12: 3165-3175.

Berget, S.M. 1995. Exon recognition in vertebrate splicing. /. Biol. Chem. 270: 2411-2414.

Chiara, M. and R. Reed. 1995. A two-step mechanism for 5 ' and 3 ' splice-site pairing. Nature 375: 510-513.

Colot, H.V., F. Stutz, and M. Rosbash. 1996. The yeast splicing factor Mud13p is a commitment complex component and corresponds to CBP20, the small subunit of the nuclear capbinding complex. Genes \& Dev. (this issuel.

Dignam, I., R. Lebowitz, and R. Roeder. 1983. Accuratc transcription initiation by RNA polymerase II in a soluble extract from mammalian nuclei. Nucleic Acids Res. 11: 14751589 .

Edery, I. and N. Sonenberg. 1985. Cap-dependent RNA splicing in a HeLa nuclear extract. Proc. Natl. Acad. Sci. 82: $7590-$ 7594.

Fu, X.-D. 1993. Specific commitment of different pre-mRNAs to splicing by SR proteins. Nature 365: 82-85.

Fu, X.-D. and T. Maniatis. 1992. The 35-kDa mammalian splicing factor SC35 mediates specific interactions between Ul and U2 small nuclear ribonucleoprotein particles at the $3^{\circ}$ splice site. Proc. Natl. Acad. Sci. 89: 1725-1729

Hamm, I. and I.W. Mattaj. 1990. Monomethylated cap structures facilitate RNA export from the nucleus. Cell 63: 109118.

Heinrichs, V. and B. Baker. 1995. The Drosophila SR protein RBPl contributes to the regulation of doublesex alternative splicing by recognising RBPI RBA target sequence. EMBO/. 14: $3987-4000$.

Hodges, P. and J. Beggs. 1994. U2 fulfils a commitment. Curr. Biol. 4: 264-267.

Hoffman, B.E. and P.J. Grabowski. 1992. Ul snRNP targets an essential splicing factor, U2AF65, to the 3' splice site by a network of interactions spanning the exon. Cienes \& Dev. 6: $2554-2568$.

Inoue, K., M. Ohno, H. Sakamoto, and Y. Shimura. 1989. Effect of the cap structure on pre-mRNA splicing in Xenopus oocyte nuclei. Genes \& Dev. 3: 1472-1479.

Izaurralde, E., J. Stepinski, E. Darzynkicwicz, and I. Mattaj. 1992. A cap binding protein that may mediate nuclear export of RNA polymerase II-transcribed RNAs. 1. Cell Biol. 118: $1287-1295$.

Izaurralde, E., J. Lewis, C. McGuigan, M. Jankowska, E. Darzynkiewicz, and I. Mattaj. 1994. A nuclear cap binding protein complex involved in pre-mRNA splicing. Cell 78: 657-668.

lzaurralde, E., J. Lewis, C. Gamberi, A. Jarmolowski, C. McGuigan, and I.W. Mattaj. 1995. A cap-binding protein complex mediating U snRNA export. Nature 376: 709-712.

Jamison, S.P.Z., J. Wang, C. Will, R. Lührmann, I. Manley, and M. Garcia-Blanco. 1995. U1 snRNP-ASF/SF2 interaction and 5 splice sitc recognition: Characterisation of required clements. Nucleic Acids Res. 23: 3260-3267.

Jarmolowski, A., W.C. Boclens, E. Izaurralde, and I.W. Mattaj. 1994. Nuclear export of different classes of RNA is mediated by specific factors. J. Cell Biol. 124: 627-635.

Kataoka, N., M. Ohno, I. Moda, and Y. Shimura. 1995. Identification of the factors which interact with NCBP, an $80 \mathrm{kDa}$ nuclear cap binding protein. Nucleic Acids Res. 23: 3638 3641 .

Kohtz, J., S. Jamison, C. Will, P. Zuo, R. Lührmann, M. GarciaBlanco, and J. Manley. 1994. Protein-protein interactions and 5 '-splice-site recognition in mammalian mRNA precur- sors. Nature 368: 119-124

Konarska, M. and P. Sharp. 1987. Interactions between small ribonucleoprotein particles in the formation of spliceosomes. Cell 49: 763-774.

Konarska, M., R. Padgett, and P. Sharp. 1984. Recognition of cap structure in splicing in vitro of mRNA precursors. Cell 38: $7.31-7.36$.

Krainer, A., T. Maniatis, B. Ruskin, and M. Green. 1984. Normal and mutant human $\beta$-globin pre-mRNAs are faithfully and efficiently spliced in vitro. Cell 36: 993-1005.

Lamm, G.M. and A.I. Lamond. 1993. Non-snRNP protein splicing factors. Biochim. Biophys. Acta 1173: 247-265.

Loreni, F., I. Ruberti, I. Bozzoni, P. Pierandrei-Amaldi, and F. Amaldi. 1985. Nucleotide sequence of the Ll ribosomal protein gene of Xenopus laevis: Remarkable sequence homology among introns. EMBO /. 4: 3483-3488.

Madhani, H. and C. Guthric. 1994. Dynamics in RNA-RNA interactions in the spliccosome. Annu. Rev. Genet. 28: 126.

Mehlin, H., B. Daneholt, and U. Skoglund. 1992. Translocation of a specific premessenger ribonucleoprotein particle through the nuclear pore studied with electron microscope tomography. Cell 69: 605-613.

- - 1995. Structural intcraction between the nuclear pore complex and a specific translocating RNP particle. /. Cell Biol. 129: 1205-1216.

Michaud, S. and R. Reed. 199l. An ATP-independent complex commits pre-mRNA to the mammalian spliceosome assembly pathway. Genes \& Dev. 5: 2534-2546.

- - 1993. A functional association between the 5 ' and $3^{\prime}$ splice sites is established in the earliest prespliceosome complex $|\mathrm{E}|$ in mammals. Genes \& Dev. 7: 1008-1020.

Moore, M., C. Query, and P. Sharp. 1993. Splicing of precursors to messenger RNAs by the spliceosome. In The RNA world led. R. Gesteland and J. Atkins\}, pp. 303-357. Cold Spring Harbor Laboratory Press, Cold Spring Harbor, New York.

Nesic, D., J. Zhang, and L.E. Maquat. 1995. Lack of an effect of the efficiency of RNA $3^{\prime}$-end formation on the efficiency of removal of either the final or the penultimate intron in intact cells. Mol. Cell. Biol. 15: 488-496.

Newman, A. 1994. Small nuclear RNAs and pre-mRNA splicing. Curr. Opin. Cell Biol 6: 360-367.

Niwa, M. and S.M. Berget. 1991. Mutation of the AAUAAA polyadenylation signal depresses in vitro splicing of proximal but not distal introns. Genes \& Dev. 5: 2086-2095.

Ohno, M., H. Sakamoto, and Y. Shimura. 1987. Preferential excision of the $5^{\prime}$ proximal intron from mRNA precursors with two introns as mediated by the cap structure. Proc. Natl. Acad. Sci. 84: 5187-5191.

Patzelt, E., E. Tahlmann, K. Hartmuth, D. Blaas, and E. Kuechler. 1987. Assembly of pre-mRNA splicing complex is cap dependent. Nucleic Acids Res. 15: 1387-1399.

Rasmussen, E. and I. Is. 1993. In vivo transcriptional pausing and cap formation on three Drosophila heat shock genes. Proc. Narl. Acad. Sci. 90: 7923-7927.

Recd, R. 1990. Protein composition of mammalian spliceosomes assembled in vitro. Proc. Natl. Acad. Sci. 87: 80318035.

Recd, R., J. Griffith, and T. Maniatis. 1988. Purification and visualisation of native splicensomes. Cell 53: 949-961.

Robberson, B.L., G.J. Cote, and S.M. Berget. 1990. Exon definition may facilitate splice site selection in RNAs with multiple exons. Mol. Cell. Biol. 10: 84-94.

Rosbash, M. and B. Seraphin. 1991. Who's on first? The Ul snRNP-5' splice sitc interaction and splicing. Trends Biochem. Sci. 16: 187-190. 


\section{Lewis et al.}

Séraphin, B. and M. Rosbash. 1989. Identification of functional U! snRNA-pre-mRNA complexes committed to spliceosome assembly and splicing. Cell 59: 349-358.

Tanaka, K., A. Watakabe, and Y. Shimura. 1994. Polypurine sequences within a downstream exon function as a splicing enhancer. Mol. Cell. Biol, 14: 1,347-1.354.

Tian, M. and T. Maniatis. 1993. A splicing enhancer complex controls alternative splicing of doublesex pre-mRNA. Cell 74: 105-114.

Visa, N., E. Izaurralde, J. Ferreira, B. Daneholt, and I.W. Mattai. 1996. A nuclear Cap Binding Complex binds Balbiani Ring pre-mRNA co-transcriptionally and accompanies the ribonucleoprotein particle during nuclear export. 1. Cell Biol. 133: $5-15$.

Wassarman, D.A. and J.A. Steitz. 1992. Interactions of small nuclear RNA's with precursor messenger RNA during in vitro splicing. Science 257: 1918-1925.

Watakabe, A., K. Tanaka, and Y. Shimura. 1993. The role of exon sequences in splice site selection. Genes \& Dev. $7: 407-418$.

Wray, W., T. Boulikas, V.P. Wray, and R. Hancock. 1981. Silver staining of proteins in polyacrylamide gels. Anol Biochem. 118: 197-203.

Zahler, A., W. Lane, J. Stolk, and M. Roth. 1992. SR proteins: A conserved family of pre-mRNA splicing factors. Genes \& Dev. 6: $8.37-847$.

Zamore, P.D. and M.R. Grcen. 1989. Identification, purification, and biochemical characterization of U2 small nuclear ribonucleoprotein auxiliary factor. Proc. Natl. Acad. Sci. 86: 9243-9247. 


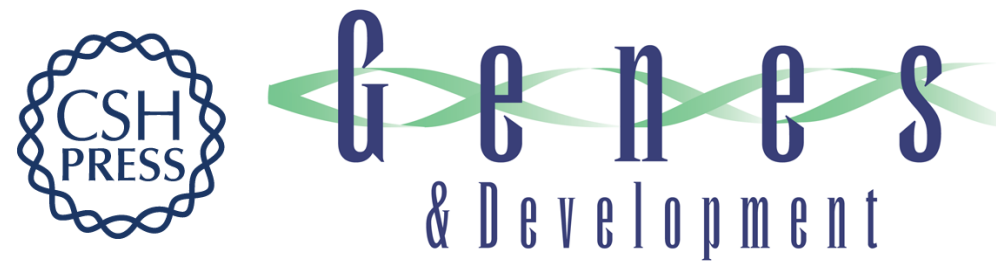

\section{A nuclear cap-binding complex facilitates association of U1 snRNP with the cap-proximal 5' splice site.}

J D Lewis, E Izaurralde, A Jarmolowski, et al.

Genes Dev. 1996, 10:

Access the most recent version at doi:10.1101/gad.10.13.1683

References This article cites 51 articles, 25 of which can be accessed free at:

http://genesdev.cshlp.org/content/10/13/1683.full.html\#ref-list-1

License

Email Alerting

Service

Receive free email alerts when new articles cite this article - sign up in the box at the top right corner of the article or click here.

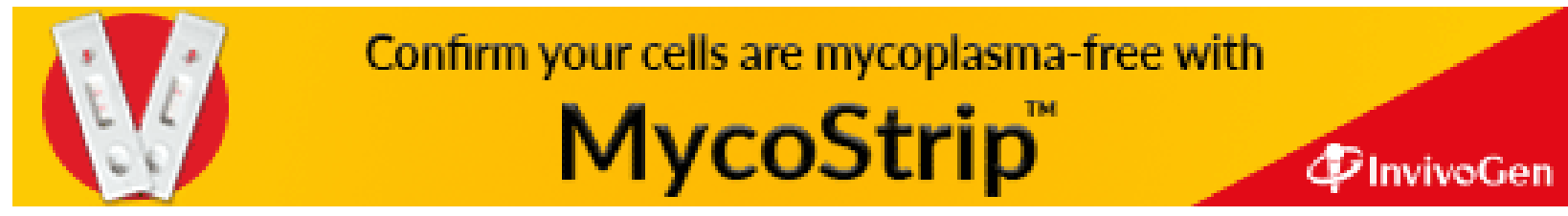

